\title{
20. GEOCHEMISTRY OF HYDROTHERMAL VENT FLUIDS FROM MIDDLE VALLEY, JUAN DE FUCA RIDGE ${ }^{1}$
}

\author{
David A. Butterfield, ${ }^{2}$ Russell E. McDuff, ${ }^{3}$ James Franklin, ${ }^{4}$ and Charles G. Wheat ${ }^{5}$
}

\begin{abstract}
Hydrothermal fluids were sampled with Alvin as part of the Ocean Drilling Program (ODP) site survey at Middle Valley in August, 1990. Hydrothermal fluids were recovered from ODP Sites 858 and 856 . Endmember fluids from Site 858 (maximum measured temperature $276^{\circ} \mathrm{C}$ ) have chlorinities near 580 millimoles $/ \mathrm{kilogram}(\mathrm{mmol} / \mathrm{kg})$, slightly higher than that of bottom seawater $\left(540 \mathrm{mmol} / \mathrm{kg}\right.$ ). Endmember fluids from Site 856 (maximum measured temperature $264^{\circ} \mathrm{C}$ ) have chlorinities of 412 $\mathrm{mmol} / \mathrm{kg}$. Except for the significant chlorinity depletion in the fluids from Site 856, the fluid chemistry is consistent with a seawater-derived source fluid reacting first with basalt at high temperature and subsequently with hemipelagic sediment. Both ammonia $(\sim 3 \mathrm{mmol} / \mathrm{kg})$ and the chalcophillic metals Fe $(10-20 \mu \mathrm{mol} / \mathrm{kg}), \mathrm{Mn}(60-80 \mu \mathrm{mol} / \mathrm{kg}), \mathrm{Cu}(0.3-1.3 \mu \mathrm{mol} / \mathrm{kg}), \mathrm{Zn}$ $(0.7-1.7 \mu \mathrm{mol} / \mathrm{kg})$, and $\mathrm{Pb}(50-100 \mathrm{nmol} / \mathrm{kg})$ are present at levels intermediate between Guaymas Basin and Escanaba Trough vent fluids, reflecting the influence of temperature on solubility. Trace metal concentrations in Middle Valley vent fluids are close to saturation with respect to magnetite and a suite of metal sulfides. Some reaction with organic matter is indicated by the elevated ammonia and bromide concentrations in the fluids. The alkali and boron systematics indicate a moderate contribution from sediments and a slightly higher water/sediment ratio for Middle Valley fluids compared with both Guaymas Basin and Escanaba Trough fluids. The site was resampled by Alvin in 1991 and by ROPOS (Remotely Operated Platform for Ocean Sciences), the Canadian remotely operated vehicle in 1992, but in both years, recovered samples contained a high percentage of entrained ambient seawater. The time series vent fluid data do not reveal significant changes in composition.
\end{abstract}

\section{INTRODUCTION}

Hydrothermal circulation is an important process altering the chemical composition of newly emplaced oceanic crust and buffering the composition of seawater through water-rock interaction. In the absence of a sedimentary cap on young oceanic crust, much of the heat and mass flux is delivered directly to seawater at high-temperature (discrete) or lowtemperature (diffuse) vents. When young oceanic crust is buried by thick sediment cover, as at Guaymas Basin, Escanaba Trough, or Middle Valley, heat is trapped, the crust stays hot longer, and hydrothermal fluids interact with sediment, precipitating metal sulfides and potentially forming large massive sulfide deposits within the sediment column. The potential exists for a wide range in the character of fluids vented from sediment-covered systems depending on the sediment composition and the extent to which the fluids react with basalt, sediment column, and buried sulfides. At one extreme, the primary hydrothermal fluids are the result of seawater-rock reactions within the basaltic crust that ascend through relatively high-permeability fault zones in the sediment column without substantial interaction with the sediments. At the other extreme, hydrothermal fluids may form by the reaction of sediment pore fluids with a basaltic sill injected into the sediment column, where recharge and discharge probably are controlled by fault zones in the sediment column. In the latter case, the chemical signature of the sediment column on the fluids would be much more pronounced because of the proximity of the intrusion (heat source) and the sediments.

Here we present data on the chemical composition of vent fluids from Middle Valley and compare them with other sedimented and un-

\footnotetext{
${ }^{1}$ Mottl, M.J., Davis, E.E., Fisher, A.T., and Slack, J.F., (Eds.), 1994. Proc, ODP, Sci. Results, 139: College Station, TX (Ocean Drilling Program).

2 Joint Institute for the Study of the Atmosphere and Ocean. University of Washington, c/o NOAA/PMEL, 7600 Sand Point Way NE, Seattle, WA 98115, U.S.A. U.S.A.

School of Oceanography WB-10, University of Washington, Seattle, WA 98105

${ }^{4}$ Geological Survey of Canada, 601 Booth St., Ottawa, Ontario K1A 0E8, Canada.

${ }^{5}$ Department of Oceanography, School of Ocean and Earth Science and Technology, University of Hawaii, 1000 Pope Road, Honolulu, HI 96822, U.S.A
}

sedimented mid-ocean ridge (MOR) fluids. These data provide some insight into the origin of the currently venting fluids in Middle Valley.

\section{GEOLOGIC SETTING}

Middle Valley is an axial rift valley at the northern extreme of the Juan de Fuca Ridge near the intersection with the Sovanco fracture zone. The valley is completely filled with Pleistocene turbiditic sediments, ranging in thickness from a few hundred meters in the southern portion to near $2 \mathrm{~km}$ in the north. Spreading is thought to have shifted from Middle Valley to West Valley around 10-15 k.y. ago.

Areas of active venting in Middle Valley were tentatively identified using the heat flow data of Davis et al. (1987) and located more precisely using deep-towed video and still-camera mapping. Active vents have been mapped in two areas of Middle Valley, near Sites 858 and 856 .

Site 858 (the Dead Dog vent field) is an elliptical area of thermally indurated sediment that forms a distinctive acoustic anomaly, about $900 \mathrm{~m}$ long and $275 \mathrm{~m}$ wide (Fig. 1). Within this area, roughly 25 separate vents have been discovered; samples were collected from eight of these during the Alvin dive series. Seismic profiles suggested that Site 858 was underlaid by a local basement high, and drilling in Holes $858 \mathrm{~F}$ and $858 \mathrm{G}$ encountered volcanic rocks starting at 250 and $275 \mathrm{~m}$ below seafloor (mbsf), respectively, and continuing for at least $160 \mathrm{~m}$ (Davis, Mottl, Fisher, et al., 1992). Beneath the Dead Dog vent field, massive sulfides ( $2.3 \mathrm{~m}$ thick) were encountered only in Hole 858B (located a few meters from an active vent).

At Site 858 vents are about evenly divided between two domains, constituting the northern and southern thirds of the acoustically anomalous area. The southern area contains the Dead Dog, Chowder Hill, and Inspired Mound vent sites, and the northern areas contain the Heineken Hollow, East Hill, and Central Site vent sites. These are representative of a larger number of vents that subsequently have been mapped in the area (Embley et al., 1992). Each vent site consists of a mound, 10 to $30 \mathrm{~m}$ in diameter and 2 to $15 \mathrm{~m}$ high. Typical of these mounds is the Chowder Hill site, where the mound is surrounded by an apron of thermally indurated, rough-textured sediment. Immediately adjacent to the mound, on its northern edge, is an area of diffuse 


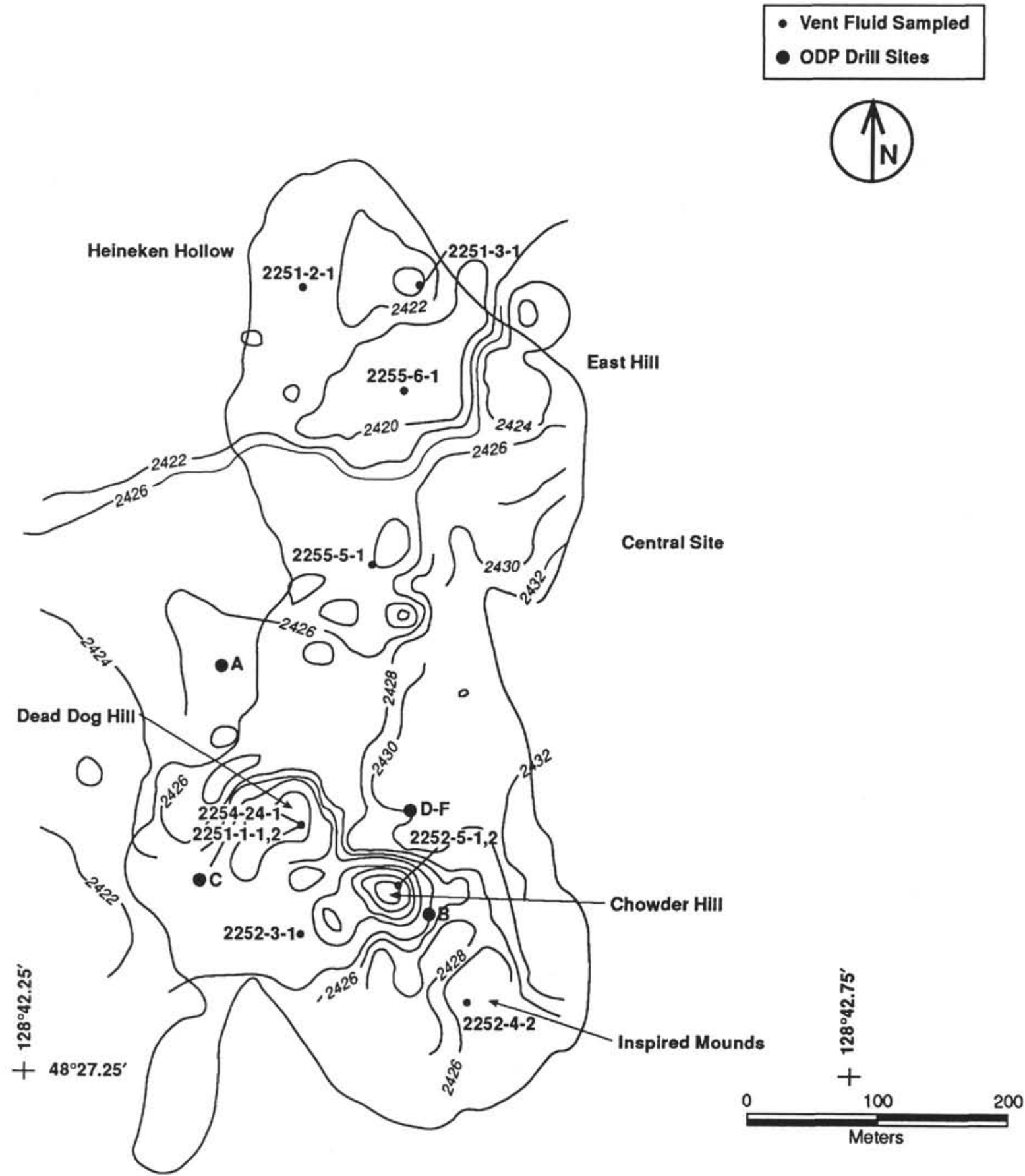

Figure 1. Map of the Dead Dog vent field, Site 858. Bold outline represents an area of high acoustic reflectivity and high heat flow (Davis, Mottl, Fisher, et al., 1992). Two-m bathymetric contours are drawn, and 1990 Alvin vent fluid sampling station numbers (see Table 1) and drill hole positions are indicated.

venting, marked by abundant calyptogena. A few vent sites have sparse clusters of vestimentiferan worms. The sides of most of the mounds are steep $\left(20^{\circ}-30^{\circ}\right)$ and are composed of areas of smooth, indurated mud and more local slabs, $1-2 \mathrm{~m}$ in diameter and $10 \mathrm{~cm}$ thick, of highly indurated sediment that have been displaced during growth of the mound. A few small active vents occur on the sides of some mounds, including Chowder Hill, while other mounds have inactive barite-rich spires on their sides. The top of each mound has a single major vent, usually composed of an anhydrite chimney, $50 \mathrm{~cm}$ to $2 \mathrm{~m}$ high, surrounded by a 3-5-m-wide apron of anhydrite rubble. The Dead Dog spire is exceptional in that it was $10 \mathrm{~m}$ high in 1992 , significantly higher than the 1990 measurement. Diffuse flow of hydrothermal fluid is prominent along the length of most of the anhydrite spires. In some, such as the Dead Dog spire, well-focused vents have formed at the base of the spire, but in most, well-focused venting is confined to the top of the spire. The spires, although 
composed dominantly of anhydrite, contain minor disseminated pyrrhotite, sphalerite, isocubanite, chalcopyrite, and galena (Ames et al., in press). The total amount of sulfide in the anhydrite matrix is small.

Temperatures (Table 1) varied from $184^{\circ} \mathrm{C}$ for a rather diffuse vent system at Heineken Hollow to $276^{\circ} \mathrm{C}$ at Chowder Hill. Temperatures were measured several times during the Alvin dive series; temperature measurements were found to fluctuate by only a few degrees at particular vents. Vent fluids were clear to slightly gray.

The second area of venting, the Bent Hill vent site, is about $350 \mathrm{~m}$ south of Holes $856 \mathrm{G}$ and $856 \mathrm{H}$ (Fig. 2). Here, the vent site consists of a single anhydrite spire that sits on a large, elongate composite mound, about $100 \mathrm{~m}$ long, $75 \mathrm{~m}$ wide, and $20 \mathrm{~m}$ high. This mound has an apron of blocks of massive sulfide and appears to be composed of pyrrhotite, sphalerite, and chalcopyrite (Ames et al., in press). The chimney is identical in appearance to those at Site 858 , including its apron of anhydrite rubble. This mound does not have attendant deformed sedimentary slabs nor evidence of the biota that are prominent at Site 858 . Vigorously venting fluids from Bent Hill vent were clear. The maximum measured temperature was constant at $265^{\circ} \mathrm{C}$ over the $\sim 1.5$ hours separating the collection of the two water samples at this vent.

Vent fluids from Site 856 were taken south of the uplifted Bent Hill, thought to have formed by the intrusion of mafic sills encountered in Holes 856A and 856B. The composition of the sills is the most primitive of any rocks recovered from the Juan de Fuca Ridge (Davis, Mottl, Fisher, et al., 1992). Site 856 is the site of a large ( $>75$-m-thick) massive sulfide deposit.

\section{METHODS}

Hydrothermal fluids were collected in 755-ml titanium major samplers (Von Damm et al., 1985) deployed from Alvin. At each vent, we attempted to avoid contaminating the samples with seawater by removing the chimney, allowing the well-focused flow to re-establish, and placing the nozzle of the titanium sampler into the lowest, clearest portion of the fluid as was possible. At a few sites (see Table 1) where venting was particularly vigorous, samples were taken from the top of a chimney. Repeated temperature measurements were made before and after sampling. In most cases, a corresponding piece of the chimney was sampled for petrographic and chemical analyses (Ames et al., in press).

Upon arrival at the surface, aliquots were removed for shipboard measurement of silica, $\mathrm{pH}$, and alkalinity. Duplicate aliquots were stored in sealed glass vials. The bulk of the fluid from each sample was stored in two plastic bottles, one acidified and one untreated. Unacidified samples were titrated with $\mathrm{AgNO}_{3}$ for chlorinity. Acidified samples were diluted on shore for ICP analysis of $\mathrm{Ca}, \mathrm{Mg}, \mathrm{Sr}, \mathrm{Ba}$, $\mathrm{K}, \mathrm{Si}, \mathrm{Fe}$, and $\mathrm{Mn}$. $\mathrm{Li}, \mathrm{Rb}, \mathrm{Fe}, \mathrm{Mn}$, and $\mathrm{Zn}$ were measured by Flame atomic absorption (AA), $\mathrm{Cu}, \mathrm{Pb}$, and $\mathrm{Cs}$ were measured by Graphite Furnace AA with Zeeman background correction. Sulfate and bromide were determined by ion chromatography. Bromide was also analyzed by iodometry, as was iodide. Total sulfur was determined by bromine oxidation of samples stored in glass vials, followed by ion chromatography. Boron was determined by a modified version of the curcumin method of Grinstead and Snider (1967). In 1992, ammonia was determined by the oxidation method described in Parsons et al. (1984). Table 2 summarizes the methods and the associated $1 \sigma$ relative standard deviations.

\section{RESULTS}

A total of 16 fluid samples were taken in 1990,14 of which were collected from vents around Site 858 and two of which were taken just south of Site 856 . Table 3 reports the endmember compositions for the two sites and the background seawater composition and Table 4 reports the chemical data for all of the samples collected.

\section{Anions}

\section{Chloride}

Endmember chlorinity in fluids from Site 858 is 580 millimoles/ kilogram (mmol/kg) and is uniform among the vents sampled (Fig. 3). This value is $7 \%$ elevated over background seawater chlorinity. The nearseafloor pore fluids sampled during Leg 139 within the vent area at Site 858 generally have higher chlorinities, ranging from 600 to $660 \mathrm{mmol} / \mathrm{kg}$ in the samples with the lowest sulfate and highest silica contents.

The two fluid samples collected near Site 856 yield an endmember chlorinity of $412 \mathrm{mmol} / \mathrm{kg} \sim 24 \%$ lower than that of ambient seawater. No pore fluids sampled during Leg 139 had chlorinities lower than seawater.

\section{Sulfate}

Sulfate was measured in acidified sample aliquots that should have lost nearly all of their $\mathrm{H}_{2} \mathrm{~S}$ by degassing during storage. The

Table 1. Vent fluid sample information.

\begin{tabular}{|c|c|c|c|c|}
\hline $\begin{array}{c}\text { Water } \\
\text { sample ID }\end{array}$ & $\begin{array}{r}\text { Sample } \\
\text { site ID }\end{array}$ & Location & $\begin{array}{l}\text { Temp } \\
{ }^{\circ} \mathrm{C}\end{array}$ & Notes \\
\hline $2251-11$ & $2251-1-1 W$ & Dead Dog Hill & 265 & $\begin{array}{l}\text { Sample from base of anhydrite spire, strong } \\
\text { flow }\end{array}$ \\
\hline $2251-13$ & $2251-2-1 \mathrm{~W}$ & Heineken Hollow & 184 & $\begin{array}{l}\text { Sample from diffuse vent at center of } \\
\text { collapse pit }\end{array}$ \\
\hline $2251-15$ & 2251-3-1W & East Hill & 274 & $\begin{array}{l}\text { Sample from top of small spire, on top of } \\
\text { Hill, strong flow }\end{array}$ \\
\hline $2251-9$ & $2251-1-2 W$ & Dead Dog Hill & 265 & Sample from top of anhydrite spire \\
\hline $2252-9$ & $2252-3-1 W$ & SW of Chowder Hill & 257 & $\begin{array}{l}\text { Sample from small chimney on the southwest } \\
\text { corner of Chowder Hill structure }\end{array}$ \\
\hline $2252-11$ & $2252-5-2 W$ & Chowder Hill & 276 & $\begin{array}{l}\text { Sample from midway up chimney; this vent } \\
\text { is about } 25 \mathrm{~m} \text { from Hole } 858 \mathrm{~B}\end{array}$ \\
\hline $2252-13$ & $2252-5-1 \mathrm{~W}$ & Chowder Hill & 276 & $\begin{array}{l}\text { Sample from base of chimney after removal } \\
\text { of spire; strong flow; same vent as } 2252-5 \text {. } \\
2 \mathrm{~W}\end{array}$ \\
\hline $2253-9$ & $2253-1-2 W$ & Bent Hill & 265 & $\begin{array}{l}\text { Sample from chimney on top of sulfide } \\
\text { mound, about } 300 \mathrm{~m} \text { south of Hole } 856 \mathrm{H} \text { : } \\
\text { sample taken } 1.5 \text { hours after } 2253-15\end{array}$ \\
\hline $2253-15$ & $2253-1-1 \mathrm{~W}$ & Bent Hill & 265 & $\begin{array}{l}\text { Sample from chimney on top of sulfide } \\
\text { mound, about } 300 \mathrm{~m} \text { south of Hole } 856 \mathrm{H}\end{array}$ \\
\hline $2254-9$ & $2254-24-3 W$ & Dead Dog Mound & 268 & Sample from base of chimney; strong venting \\
\hline $2254-13$ & $2254-24-1 \mathrm{~W}$ & Dead Dog Mound & 268 & Sample from base of chimney; strong venting \\
\hline $2254-15$ & $2254-24-2 W$ & Dead Dog Mound & 268 & Sample from base of chimney; strong venting \\
\hline $2255-13$ & $2255-5-1 W$ & Central Site & 256 & $\begin{array}{l}\text { Sample from base of } 2 \mathrm{~m} \text { anhydrite chimney, } \\
\text { after breaking off chimney; vigorous venting }\end{array}$ \\
\hline $2255-15$ & $2255-6-1 W$ & W of East Hill & 245 & $\begin{array}{l}\text { Sample from base of broken chimney; } \\
\text { moderate strength venting }\end{array}$ \\
\hline $2255-9$ & $2255-4-2 \mathrm{~W}$ & Inspire & 254 & Sample from small vent on top of hill \\
\hline $2255-11$ & $2255-4-1 \mathrm{~W}$ & N Inspired Mound & 254 & Sample from nearby vent to $2255-4-2 \mathrm{~W}$ \\
\hline
\end{tabular}



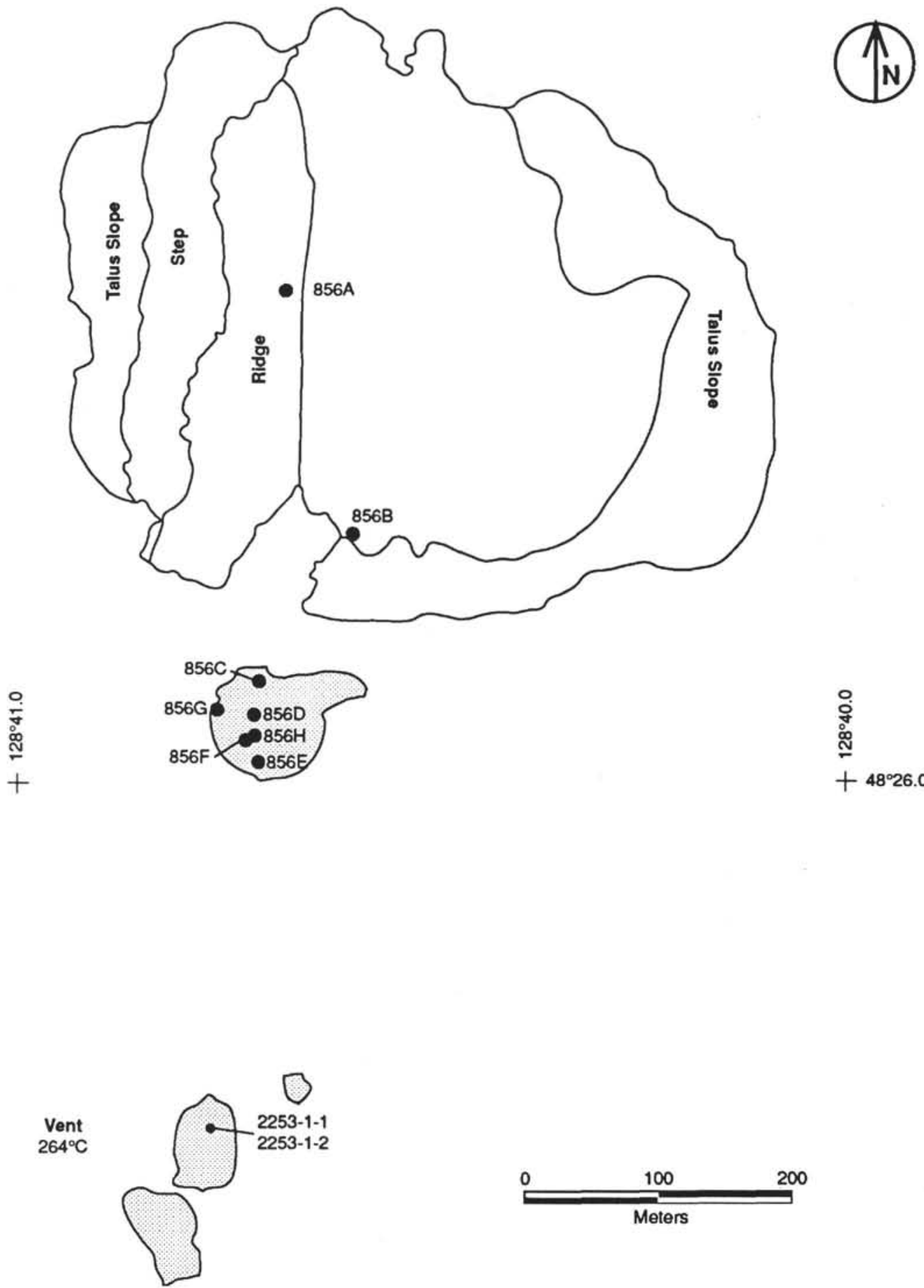

Figure 2. Map of the Bent Hill vent site, $\sim 300 \mathrm{~m}$ south of Site 856. The outline of Bent Hill occupies the top (northern) half of the figure. Stippled areas represent outcrops of massive sulfide. The single vent sampled on dive 2253 is an anhydrite chimney on top of a sulfide mound.

extrapolated zero-magnesium sulfate concentration is $\sim 0.4 \mathrm{mmol} / \mathrm{kg}$ for both sites (Fig. 3). Unlike the pore fluids, the vent fluids are nearly completely lacking in sulfate and magnesium, reflecting high-temperature reaction conditions.

\section{Bromide}

Relative to seawater, bromide is enriched in the vent fluids from both sites on a chloride-normalized basis. The bromide to chloride ratio in the Middle Valley vent fluids is $1.86 \times 10^{-3}$, compared with the seawater ratio of $1.56 \times 10^{-3}$. Bromide enrichment is common in fluids that have reacted with organic matter in sediments (Campbell and Edmond, 1989; Magenheim and Gieskes, 1992).

\section{Other Constituents}

\section{Alkalinity and $\mathrm{pH}$}

Endmember alkalinities for most of the fluids sampled at Site 858 are close to 1.5 milliequivalents $/$ kilogram $(\mathrm{meq} / \mathrm{kg})$, while alkalini- 
Table 2. Analytical methods and associated uncertainties.

\begin{tabular}{|c|c|c|}
\hline Analyte & Technique & $\begin{array}{c}\text { Precision, } \% \\
1 \sigma\end{array}$ \\
\hline $\mathrm{pH}$ & Potentiometric & 0.3 \\
\hline Alkalinity & Potentiometric titration & 1 \\
\hline $\mathrm{Cl}$ & $\mathrm{AgNO}_{3}$ titration, visual endpoint & 0.2 \\
\hline $\mathrm{SO}_{4}$ & Ion chromatography & 2 \\
\hline $\mathrm{Br}^{4}$ & Ion chromatography and iodometry & 5 \\
\hline $\mathrm{Mg}, \mathrm{Ca}$ & EDTA-EGTA titration or ICP-AES & 0.5 or 1 \\
\hline $\mathrm{Ba}$ & ICP-AES & 8 \\
\hline $\mathrm{Sr}$ & ICP-AES & 0.5 \\
\hline $\mathrm{K}$ & Flame atomic emission (FAE) & 2 \\
\hline $\mathrm{Li}$ & Flame atomic absorption (FAA) & 2 \\
\hline $\mathrm{Rb}$ & FAE standard additions & 4 \\
\hline Cs & Zeeman GFAA, standard additions & 9 \\
\hline $\mathrm{Si}$ & Colorimetric silico-molybdate blue or ICP-AES & 1 \\
\hline $\mathrm{NH}_{3}$ & oxidation method & 5 \\
\hline $\mathrm{H}_{2} \mathrm{~S}$ & Difference between total sulfur and sulfate & 10 \\
\hline $\mathrm{Fe}, \mathrm{Mn}, \mathrm{Zn}$ & ICP-AES & 2 \\
\hline $\mathrm{Fe}, \mathrm{Mn}, \mathrm{Zn}$ & Graphite furnace A.A. (at low concentrations) & 5 \\
\hline $\mathrm{Cu}$ & Graphite furnace A.A. & 2 \\
\hline $\mathrm{Pb}$ & Graphite fumace A.A. & 10 \\
\hline B & Colorimetric, curcumin & 2 \\
\hline
\end{tabular}

ties of samples from the southern area (Chowder Hill and Inspired Mound) are in the range 1.8 to $2.0 \mathrm{meq} / \mathrm{kg}$ (Fig. 4). The samples from Site 856 yield an endmember of $1.45 \mathrm{meq} / \mathrm{kg}$. The high alkalinities seen in some pore fluids ( $>4 \mathrm{meq} / \mathrm{kg}$ ) due to bacterial degradation of organic matter are not seen in the vent fluids.

The shipboard-measured $\mathrm{pH}$ for near-endmember fluids is 5.5 at Site 858 and 5.15 at Site 856 (Fig. 4).

\section{Hydrogen Sulfide}

$\mathrm{H}_{2} \mathrm{~S}$ concentration was calculated as the difference between total sulfur and sulfate due to a problem with sulfide preservation. Samples sealed in glass vials (which partially oxidized during storage) were oxidized with bromine to convert all sulfur species to sulfate, which was then measured by ion chromatography. Sulfate was also measured on acidified sample aliquots, from which $\mathrm{H}_{2} \mathrm{~S}$ should have been lost by degassing during storage. Because of the possible errors associated with this procedure, we estimate an average endmember $\mathrm{H}_{2} \mathrm{~S}$ concentration for the entire Middle Valley suite of samples only, rather than $\mathrm{H}_{2} \mathrm{~S}$ estimates for individual vents. The average endmember $\mathrm{H}_{2} \mathrm{~S}$ concentration for Middle Valley vent fluids is $2.9 \pm 0.8 \mathrm{mmol} / \mathrm{kg}$.

Total $\mathrm{CO}_{2}$ concentrations are approximately 4 to $5 \mathrm{mmol} / \mathrm{kg}$ in fluids from Site 858 and approximately $12 \mathrm{mmol} / \mathrm{kg}$ in fluids from Site 856 (B.E. Taylor, pers. comm., 1993). Other volatile data are not available.

\section{Boron}

Boron (Fig. 4) reaches concentrations approximately 4 times that of seawater in the endmember fluids at Middle Valley. Boron concentrations in unsedimented MOR hydrothermal systems are within $50 \%$ of seawater boron concentration, with the exception of the Endeavour Ridge vent fluids (Butterfield et al., in press; C.-F. You et al., unpubl. data). Boron isotope measurements (J. Gieskes, C.-F. You, and D. Butterfield, unpubl. data) indicate that the excess boron in Middle Valley fluids is derived from sediment.

\section{Silica}

Silica (Fig. 4) was measured both aboard ship by molybdate chemistry and on shore by ICP emission spectrometry. In all cases, endmembers extrapolated from the two data sets agree to within the uncertainty of the regression.

A composite of all the vents sampled at Site 858 yields an endmember silica concentration of $10.18 \pm 0.5 \mathrm{mmol} / \mathrm{kg}\left(\mathrm{r}^{2}=0.989\right)$. Endmembers for individual vents are $9.5 \pm 1 \mathrm{mmol} / \mathrm{kg}$ at Dead Dog, $10.21 \pm 0.23$ at Chowder Hill, and $10.40 \pm 0.05$ at Inspired Mound. At Site 856, the silica endmember concentration is $10.35 \pm 0.25$ $\mathrm{mmol} / \mathrm{kg}$. Using the model of Von Damm et al. (1991) and the den-
Table 3. Middle Valley fluid endmember composition.

\begin{tabular}{|c|c|c|c|c|}
\hline Vent & & $\begin{array}{c}\text { Dead Dog } \\
\text { Site } 858 \text { avg }\end{array}$ & $\begin{array}{l}\text { Bent Hill } \\
\text { Site } 856\end{array}$ & Seawater \\
\hline Temp. & $\max ,{ }^{\circ} \mathrm{C}$ & 276 & 265 & 2.5 \\
\hline $\mathrm{pH}$ & $1 \mathrm{~atm}, 25^{\circ} \mathrm{C}$ & 5.5 & 5.13 & 7.5 \\
\hline Alkalinity & $\mathrm{meq} / \mathrm{kg}$ & $1.4-2.0$ & 1.45 & 2.45 \\
\hline $\mathrm{Cl}$ & $\mathrm{mmol} / \mathrm{kg}$ & 578 & 412 & 540 \\
\hline Sulfate & $\mathrm{mmol} / \mathrm{kg}$ & 0.4 & 0.4 & 28 \\
\hline $\mathrm{Br}$ & $\mu \mathrm{mol} / \mathrm{kg}$ & 1070 & 770 & 845 \\
\hline $\mathrm{Br} / \mathrm{Cl}$ & $\mathrm{\mu mol} / \mathrm{mmol}$ & 1.85 & 1.87 & 1.56 \\
\hline $\mathrm{NH}_{3}$ & $\mathrm{mmol} / \mathrm{kg}$ & 2.8 & $?$ & 0.002 \\
\hline $\mathrm{H}_{2} \mathrm{~S}$ & $\mathrm{mmol} / \mathrm{kg}$ & 3 & 3 & 0 \\
\hline $\mathrm{B}^{2}$ & $\mu \mathrm{mol} / \mathrm{kg}$ & 1730 & 1600 & 420 \\
\hline $\mathrm{Si}$ & $\mathrm{mmol} / \mathrm{kg}$ & $9.7-10.6$ & 10.3 & 0.18 \\
\hline $\mathrm{Li}$ & $\mu \mathrm{mol} / \mathrm{kg}$ & $430-550$ & 370 & 28 \\
\hline $\mathrm{Na}$ & $\mathrm{mmol} / \mathrm{kg}$ & 398 & 315 & 460 \\
\hline $\mathrm{Na} / \mathrm{Cl}$ & $\mathrm{mol} / \mathrm{mol}$ & 0.689 & 0.765 & 0.852 \\
\hline $\mathrm{K}$ & $\mathrm{mmol} / \mathrm{kg}$ & 18.7 & 13.5 & 9.95 \\
\hline $\mathrm{Rb}$ & $\mu \mathrm{mol} / \mathrm{kg}$ & 31 & 22.5 & 2 \\
\hline Cs & $\mathrm{nmol} / \mathrm{kg}$ & 1400 & 1000 & 3 \\
\hline $\mathrm{Mg}$ & $\mathrm{mmol} / \mathrm{kg}$ & 0 & 0 & 52.8 \\
\hline $\mathrm{Ca}$ & $\mathrm{mmol} / \mathrm{kg}$ & 81 & 40 & 10.28 \\
\hline $\mathrm{Sr}$ & $\mu \mathrm{mol} / \mathrm{kg}$ & 257 & 162 & 87 \\
\hline $\mathrm{Sr} / \mathrm{Ca}$ & $\mu \mathrm{mol} / \mathrm{mmol}$ & 3.17 & 4.05 & 8.46 \\
\hline $\mathrm{Ba}$ & $\mu \mathrm{mol} / \mathrm{kg}$ & $\sim 15$ & $\sim 15$ & 0.14 \\
\hline $\mathrm{Mn}$ & $\mu \mathrm{mol} / \mathrm{kg}$ & 63 & 78 & 0.005 \\
\hline $\mathrm{Fe}$ & $\mu \mathrm{mol} / \mathrm{kg}$ & $10-20$ & 17 & 0.005 \\
\hline $\mathrm{Cu}$ & $\mu \mathrm{mol} / \mathrm{kg}$ & $0.6-1.3$ & $0.3-1.3$ & 0.007 \\
\hline $\mathrm{Zn}$ & $\mu \mathrm{mol} / \mathrm{kg}$ & $0.9-1.7$ & 0.7 & 0.01 \\
\hline $\mathrm{Pb}$ & $\mathrm{nmol} / \mathrm{kg}$ & $95-125$ & 50 & 0.01 \\
\hline${ }^{87} \mathrm{Sr} /{ }^{86} \mathrm{Sr}$ & & 0.70424 & 0.70436 & 0.70918 \\
\hline
\end{tabular}

sity data of Potter and Brown (1977), we calculate quartz solubility for conditions relevant to Middle Valley hydrothermal fluids. Minor quartz is present in hydrothermally altered sediments from Middle Valley (Goodfellow et al., in press). For the maximum measured exit temperature of $275^{\circ} \mathrm{C}$ at Site 858 and the endmember silica concentration of $10.2 \mathrm{mmol} / \mathrm{kg}$, a reaction pressure of approximately 230 bars is indicated (seafloor pressure is $\sim 250$ bars). The uncertainty in the silica endmember concentration translates to an uncertainty in pressure of nearly 50 bars, allowing us to conclude that the high-temperature fluids are in equilibrium with quartz within $\sim 500 \mathrm{~m}$ of the seafloor. Since quartz solubility increases rapidly with temperature, it is unlikely that the Middle Valley hydrothermal fluids are significantly hotter in the near subseafloor upflow zone.

\section{Ammonia}

Ammonia was not measured in the vent fluids collected in 1990. However, we did measure ammonia on a single vent fluid sample from Dead Dog Hill, and on pore waters separated from a push-core taken in a clam bed in a high heat-flow area on Chowder Hill during the 1992 ROPOS (Remotely Operated Platform for Ocean Sciences) expedition. By extrapolating the ammonia-silica trend to $10 \mathrm{mmol} / \mathrm{kg}$ silica (the vent-fluid endmember), we estimate that the endmember ammonia concentration in the vent fluids is $2.9 \pm 0.5 \mathrm{mmol} / \mathrm{kg}$. The pore fluids have somewhat higher ammonia to silica ratios. This shows the influence of the degradation of organic matter on the vent and pore fluid composition. As is the case for other indicators of organic matter involvement, the ammonia levels at Middle Valley are considerably lower than at Guaymas Basin $(\sim 15 \mathrm{mmol} / \mathrm{kg})$.

\section{Alkali Elements}

The alkali elements and other major cations in Middle Valley vent fluids from the two sites sampled are enriched roughly in proportion to the chlorinity of the fluids; i.e., Site 856 fluids are lower in all major cations than Site 858 fluids.

\section{Lithium}

Endmember lithium concentrations in fluids from Site 858 (Fig. 5) range from 430 to 550 micromoles $/ \mathrm{kg}(\mu \mathrm{mol} / \mathrm{kg})$. Fluids from Site 
Table 4. Middle Valley fluid data.

\begin{tabular}{|c|c|c|c|c|c|c|c|c|c|c|c|c|c|c|c|c|}
\hline Sample \# & Vent & $\begin{array}{c}\text { Temp } \\
\mathrm{C}^{\circ}\end{array}$ & $\begin{array}{c}\mathrm{pH} \\
@ 25^{\circ} \mathrm{C}\end{array}$ & $\begin{array}{c}\text { Alk } \\
\mathrm{mmol} / \mathrm{kg}\end{array}$ & $\begin{array}{c}\mathrm{Si} \\
\mathrm{mmol} / \mathrm{kg}\end{array}$ & $\begin{array}{c}\mathrm{H} 2 \mathrm{~S} \\
\mu \mathrm{mol} / \mathrm{kg}\end{array}$ & $\begin{array}{c}\mathrm{Cl} \mathrm{mmol} / \mathrm{kg} \\
\text { titration }\end{array}$ & $\begin{array}{c}\mathrm{Br} \\
\mu \mathrm{mol} / \mathrm{kg}\end{array}$ & $\begin{array}{c}\mathrm{SO} 4 \\
\mathrm{mmol} / \mathrm{l}\end{array}$ & $\begin{array}{c}\mathrm{Li} \\
\mu \mathrm{mol} / \mathrm{kg}\end{array}$ & $\begin{array}{c}\mathrm{Na} \\
\mathrm{mmol} / \mathrm{kg}\end{array}$ & $\underset{\mathrm{mmol} / \mathrm{kg}}{\mathrm{K}}$ & $\begin{array}{c}\mathrm{Rb} \\
\mu \mathrm{mol} / 1\end{array}$ & $\begin{array}{c}\mathrm{Cs} \\
\mathrm{nmol} / \mathrm{kg}\end{array}$ & $\begin{array}{c}\mathrm{Mg} \\
\mathrm{mmol} / \mathrm{kg}\end{array}$ & $\begin{array}{c}\mathrm{Ca} \\
\mathrm{mmol} / \mathrm{kg}\end{array}$ \\
\hline Seawater & Ambient & 2.1 & 7.54 & 2.45 & 0.175 & 0 & 541 & 850 & 28.2 & 28 & 461 & 9.98 & 1.7 & 2 & 53 & 10.23 \\
\hline & & & & & & & & & & & & & \multicolumn{4}{|c|}{1990 Alvin samples } \\
\hline $2255-9$ & Inspired Mound & 254 & 5.56 & 1.82 & 6.94 & 2.92 & 566.2 & 980 & 10.55 & 295 & 423 & 16.2 & 22.43 & 1107 & 17.30 & 57.19 \\
\hline $2255-11$ & Inspired Mound & 254 & 5.61 & 1.94 & 7.82 & & 566 & 1018 & 7.98 & 329 & 414 & 16.7 & & 933 & 11.51 & 64.5 \\
\hline $2251-13$ & Heineken Hollow & 184 & 6.54 & 2.27 & 0.92 & & 543.15 & 862 & 26.71 & 82.7 & 456 & 10.9 & 4.8 & & 47.74 & 16.60 \\
\hline $2255-15$ & East Hill & 245 & 7.13 & 2.35 & 0.32 & & 540.5 & 810 & 26.99 & 32.3 & 461 & 9.7 & 2.63 & & 50.54 & 11.22 \\
\hline $2251-15$ & East Hill & 274 & 5.48 & & 9.76 & 3.64 & 585 & 1058 & 2.21 & 492 & 404 & 18.8 & 27.88 & 1304 & 2.36 & 80.23 \\
\hline $2254-13$ & Dead Dog & 268 & 5.50 & 1.34 & 9.46 & & 577.1 & 1061 & 2.38 & 428 & 403 & 17.7 & 28.16 & 1347 & 2.83 & 76.80 \\
\hline $2251-11$ & Dead Dog & 265 & 5.75 & 1.68 & 5.36 & & 560.8 & 967 & 15.75 & 256 & 437 & 14.1 & 16.25 & & 26.61 & 43.44 \\
\hline $2251-9$ & Dead Dog & 265 & 5.54 & 1.55 & 8.95 & 1.09 & 578 & 1051 & 2.61 & 450 & 403 & 18.7 & 29.93 & 1375 & 3.27 & 76.88 \\
\hline $2254-15$ & Dead Dog & 268 & 5.58 & 1.52 & 7.05 & & 570.6 & 1010 & 5.93 & 451 & 406 & 18.1 & & 1287 & 3.8 & 75.5 \\
\hline $2254-9$ & Dead Dog & 268 & 5.75 & 1.68 & 5.84 & & 580 & 984 & 14.7 & 349 & 464 & 13.2 & & & 27.63 & 38.17 \\
\hline $2252-11$ & Chowder Hill & 276 & 7.06 & 2.504 & 0.48 & & 549.15 & 870 & 28 & 51.2 & 468 & 10.1 & 2.24 & & 50.73 & 12.47 \\
\hline $2252-13$ & Chowder Hill & 276 & 5.56 & 1.85 & 9.61 & 1.82 & 576.9 & 1065 & 4.64 & 490 & 407 & 17.3 & 28.82 & & 4.33 & 75.57 \\
\hline $2252-9$ & Chowder Hill & 257 & 5.55 & 1.95 & 9.70 & & 576.3 & 1082 & 2.05 & 534 & 399 & 18 & & & 1.6 & 80.6 \\
\hline $2255-13$ & Central Site & 256 & 5.98 & 2.09 & 3.19 & & 550.8 & 881 & 21.29 & 156 & 448 & 12.1 & 8.76 & & 38.31 & 28.04 \\
\hline 2253-9 & Bent Hill & 265 & 5.13 & 1.51 & 9.22 & & 424.7 & 774 & 2.51 & 337 & 332 & 13.3 & 22.84 & 942 & 3.30 & 38.21 \\
\hline \multirow[t]{2}{*}{$2253-15$} & Bent Hill & 265 & 5.14 & 1.44 & 10.68 & 2.4 & 409.5 & 769 & 1.61 & 377 & 316 & 13.4 & 19.49 & 1067 & 0.65 & 40.25 \\
\hline & & & & & & & & & & & & & \multicolumn{4}{|c|}{ 1991 Alvin samples } \\
\hline $2458-1$ & Chowder Hill & 90 & 6.71 & 2.447 & 1.37 & 0.137 & 540.9 & & 24.03 & 80.5 & 436 & 10.95 & 3.59 & & 46.26 & 18.21 \\
\hline $2458-2$ & Chowder Hill & 90 & 7.97 & 2.695 & 0.534 & 0.001 & 534.3 & & 28.83 & 33.6 & 457 & 10 & 1.73 & & 50.13 & 12.82 \\
\hline \multirow[t]{2}{*}{$2458-3$} & Chowder Hill & 90 & 7.12 & 2.517 & 2.09 & 0.033 & 533.4 & & 22.97 & 113 & 442 & 11.69 & 5.5 & & 41.88 & 24.57 \\
\hline & & & & & & & & & & & & & \multicolumn{4}{|c|}{1992 ROV samples } \\
\hline \multirow[t]{2}{*}{ hys 199} & Dead Dog & 260 & 7.43 & 2.67 & 0.334 & 0.019 & 554 & & & & & & & & 51.39 & 11.3 \\
\hline & & & & & & & & & & & & & \multicolumn{4}{|c|}{1992 sediment pore fluids } \\
\hline $0-4 \mathrm{~cm}$ & Chowder Hill & & 7.55 & & 0.954 & 0.069 & 546.3 & & & & & & & & & \\
\hline $4-8 \mathrm{~cm}$ & & & 7.68 & & 1.243 & 0.489 & 547.4 & & & & & & & & & \\
\hline $0-8 \mathrm{~cm}$ & & & 7.40 & & 1.136 & 0.17 & 549.4 & & & & & & & & & \\
\hline
\end{tabular}

Table 4 (continued).

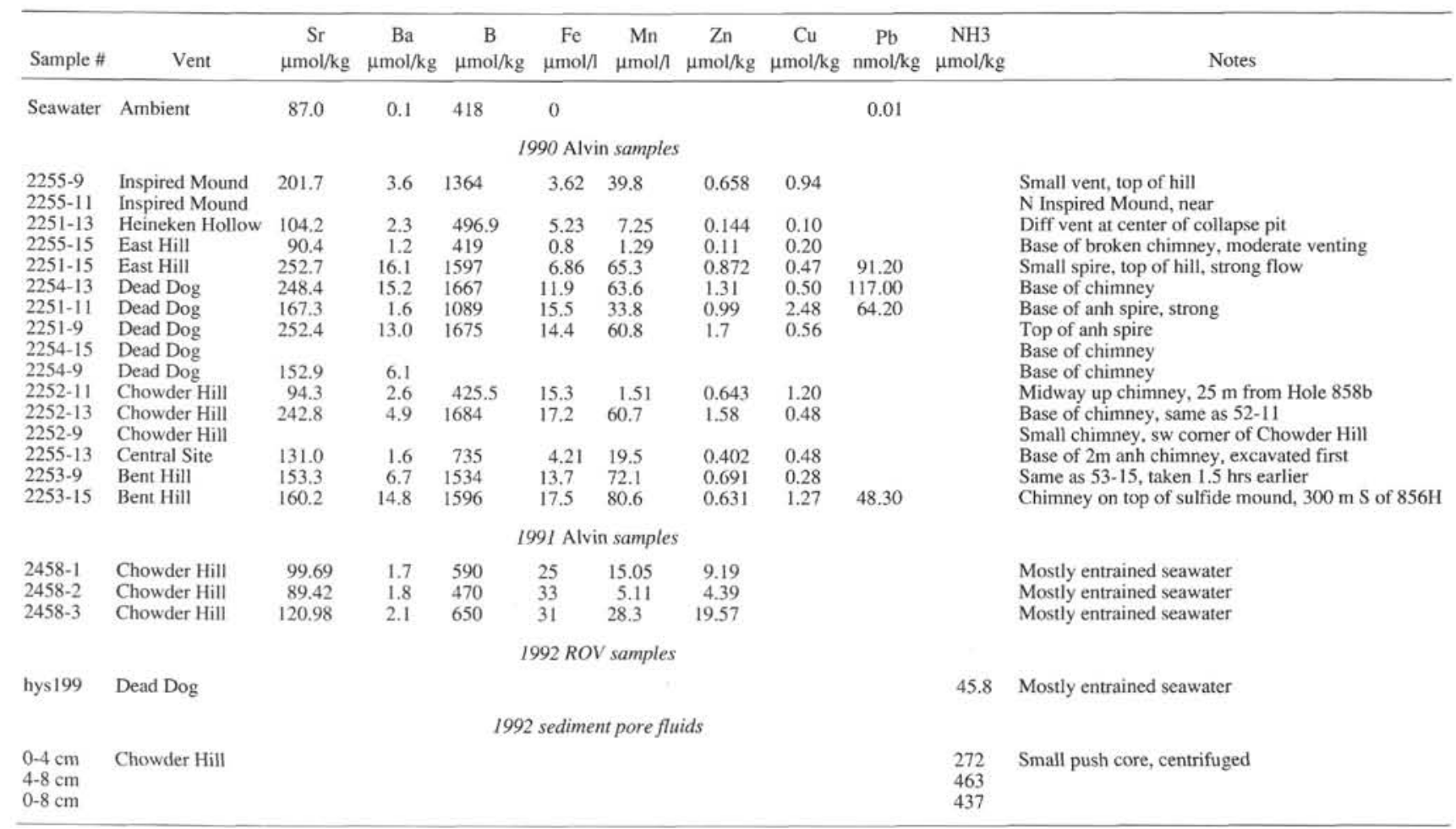



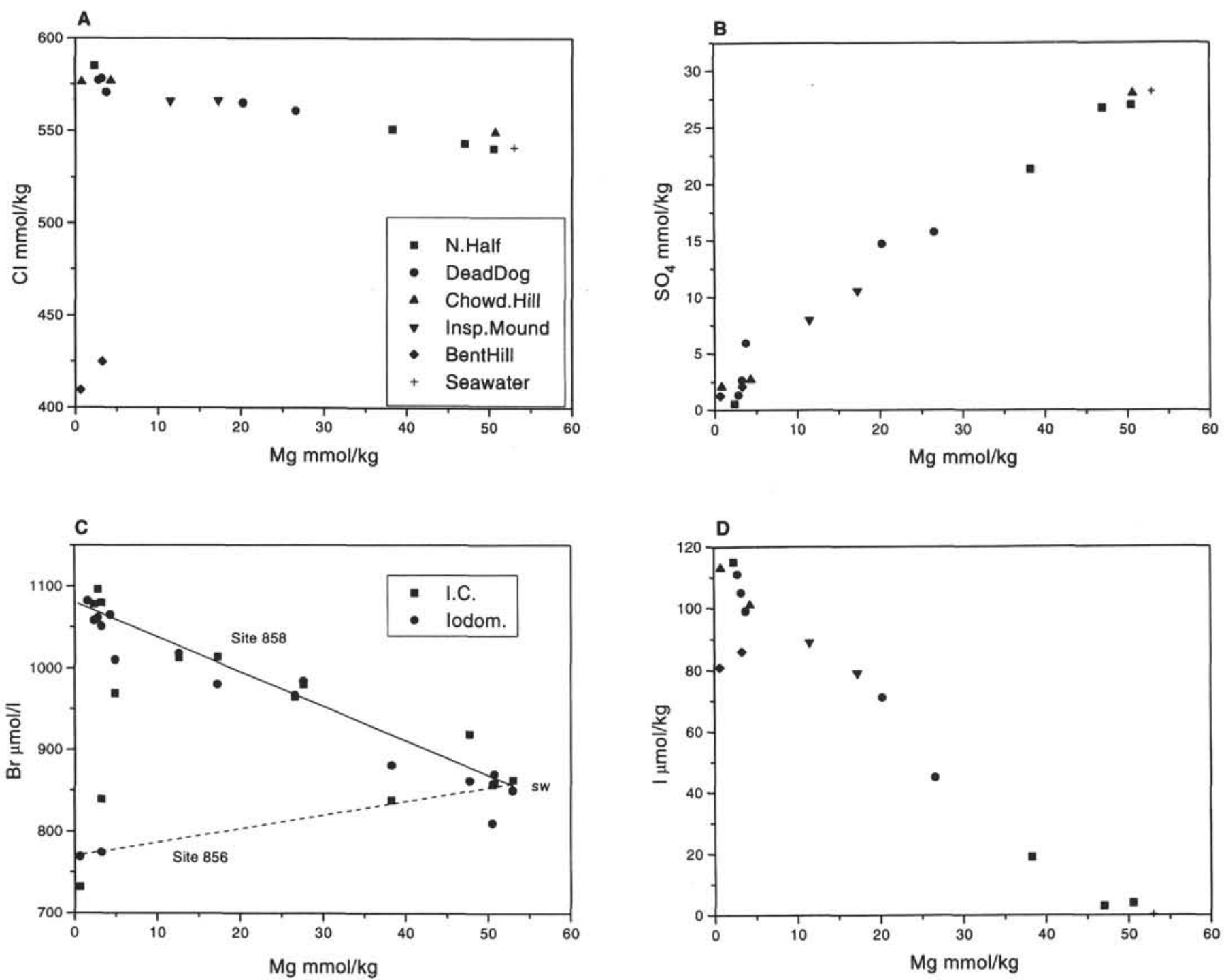

Figure 3. Anions vs. magnesium. Samples are dilutions of near zero-magnesium endmember fluids with ambient seawater. A. Chloride. B. Sulfate. C. Bromide. D. Iodide.

856 have lower $\operatorname{Li}(370 \mu \mathrm{mol} / \mathrm{kg})$. These levels are on the low end of the range for all vent fluids (Von Damm, 1990).

\section{Sodium}

Sodium (calculated by charge balance) has an endmember concentration of $398 \mathrm{mmol} / \mathrm{kg}$ at Site 858 and $315 \mathrm{mmol} / \mathrm{kg}$ at Site 856 (Fig. 5). The $\mathrm{Na} / \mathrm{Cl}$ ratios are 0.686 and 0.765 for Sites 858 and 856 , respectively. These ratios show significant sodium depletion relative to seawater $(\mathrm{Na} / \mathrm{Cl}=0.852)$.

\section{Potassium}

Potassium is enriched in vent fluids from both sites, reaching $\sim 18.7 \mathrm{mmol} / \mathrm{kg}$ at Site 858 and $13.5 \mathrm{mmol} / \mathrm{kg}$ at Site 856 , relative to $9.95 \mathrm{mmol} / \mathrm{kg}$ in seawater (Fig. 5).

\section{Rubidium}

Rubidium reaches $\sim 31 \mu \mathrm{mol} / \mathrm{kg}$ at Site 858 and $22.5 \mu \mathrm{mol} / \mathrm{kg}$ at Site 856 (Fig. 5). These concentrations are at the high end of the range for sediment-starved MOR fluids, and are considerably lower than the $60-100 \mu \mathrm{mol} / \mathrm{kg}$ levels found in vent fluids at Guaymas Basin and Escanaba Trough (You et al., in press).

\section{Cesium}

Cesium is highly enriched in Middle Valley vent fluids, with endmembers of 1400 nanomoles $/ \mathrm{kg}(\mathrm{nmol} / \mathrm{kg})$ at Site 858 and 1000 $\mathrm{nmol} / \mathrm{kg}$ at Site 856 (Fig. 5), compared with seawater levels of $\sim 2$ $\mathrm{nmol} / \mathrm{kg}$. High Cs levels are characteristic of sedimented hydrothermal systems. Cs concentrations in Middle Valley fluids are higher than the typical 100 to $300 \mathrm{nmol} / \mathrm{kg}$ in sediment-starved MOR fluids, but do not reach the 5800 to $7700 \mathrm{nmol} / \mathrm{kg}$ levels of vent fluids from Guaymas Basin and Escanaba Trough (Campbell et al., in press). Alkali systematics are discussed further below.

\section{Alkaline Earths}

\section{Magnesium}

Magnesium is nearly completely removed from hydrothermal fluids during high-temperature reaction with rocks and sediments (Bischoff and Dickson, 1975; Mottl and Holland, 1978). We recov- 

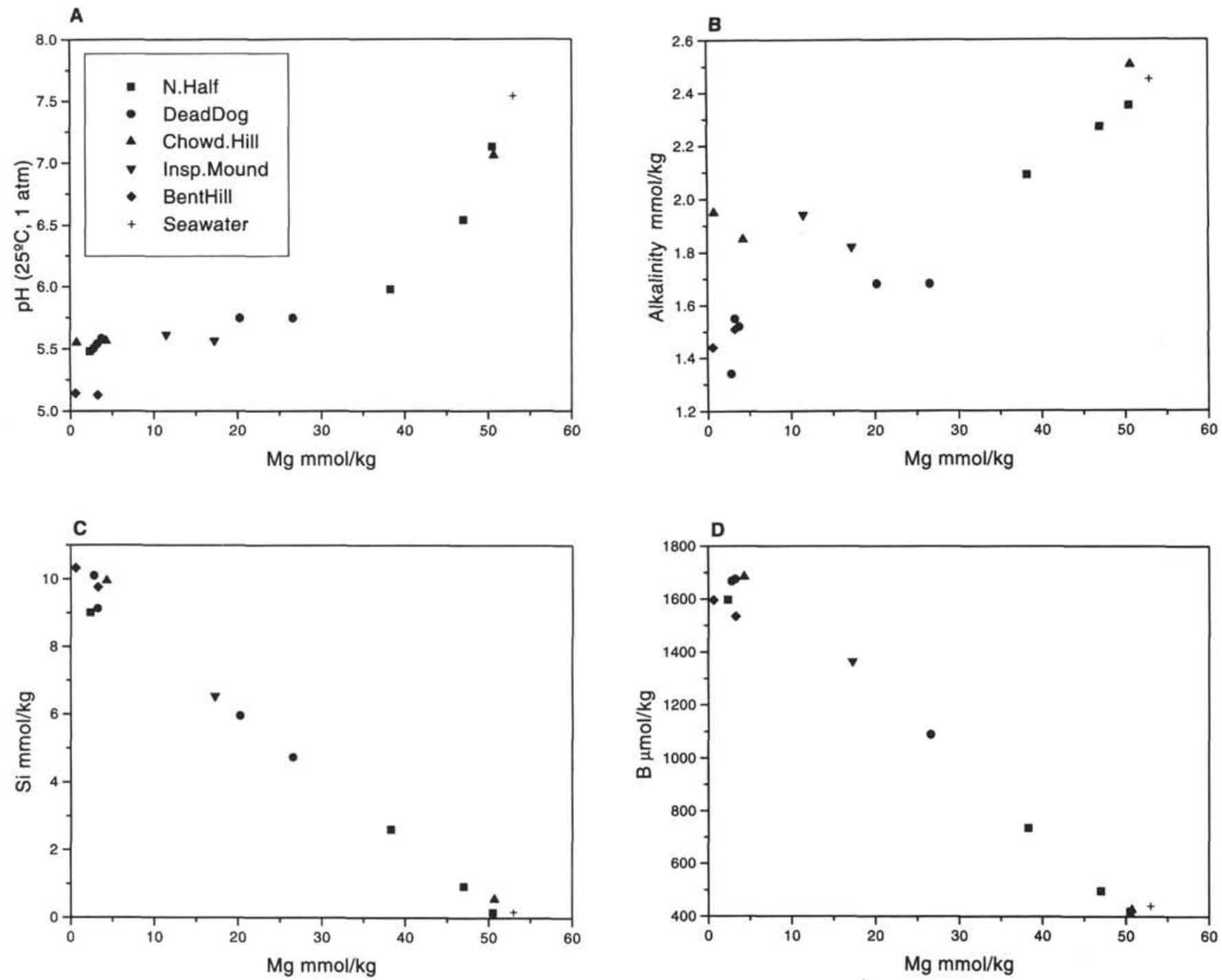

Figure 4. Plots of various vent fluid constituents vs. magnesium. A. $\mathrm{pH}$ measured at $25^{\circ} \mathrm{C}$ and 1 atmosphere. B. Alkalinity. C. Silica. D. Boron.

ered samples with a range of magnesium and sulfate values, including some low magnesium and sulfate, consistent with dilution of zeromagnesium, high-temperature fluids with ambient seawater.

\section{Calcium}

Calcium in the Site 858 hydrothermal fluids reaches $82 \mathrm{mmol} / \mathrm{kg}$ (Fig. 6), which is higher than any other MOR hydrothermal site except the Cleft Segment of the Juan de Fuca Ridge, where chlorinities are $>200 \%$ of seawater levels. Calcium in Guaymas Basin hydrothermal fluids is only $\sim 28 \mathrm{mmol} / \mathrm{kg}$ (Campbell et al., 1988; Gieskes et al., 1988). The high calcium levels in Middle Valley vent fluids are similar to those of pore fluids from Leg 139.

Along with the lower chlorinity in Site 856 fluids, the calcium endmember concentration $(40 \mathrm{mmol} / \mathrm{kg})$ is markedly lower.

\section{Strontium}

The strontium endmember concentration at Site 858 is $257 \mu \mathrm{mol} /$ $\mathrm{kg}$ (Fig. 6), which is higher than that measured in fluids from any other sedimented or unsedimented ridge-crest hydrothermal system, except the Cleft Segment. The $\mathrm{Sr} / \mathrm{Ca}$ ratio in fluids from Site 858 is $3.17 \cdot 10^{-3}$, which is at the low end of the range of values for hydrothermal vents.
At Site 856 , the strontium endmember $(162 \mu \mathrm{mol} / \mathrm{kg})$ is lower and the $\mathrm{Sr} / \mathrm{Ca}$ ratio is higher than at Site 858 .

The endmember ${ }^{87} \mathrm{Sr} /{ }^{86} \mathrm{Sr}$ ratio for fluids from both sites is $\sim 0.7043$, compared to seawater $(0.7091)$ and basalt $(\sim 0.7029)$.

\section{Barium}

Endmember barium concentration is $\sim 15 \mu \mathrm{mol} / \mathrm{kg}$ in fluids from both Middle Valley sites (Fig. 6). According to our calculations with the chemical speciation program MINEQL (Westall et al., 1976; Tivey, 1988), the fluids are slightly undersaturated with respect to barite under in-situ conditions.

\section{Transition Metals}

All measured transition metals are present in low concentrations relative to unsedimented MOR vent fluids, and are similar to, but slightly lower than the concentrations reported for Guaymas Basin fluids. Since the levels are low, only minor particle entrainment (due in part to excavation of chimneys prior to sampling) and subsequent particle dissolution (in the sample bottles after acidification) can cause significant errors in trace metal concentrations. These problems 

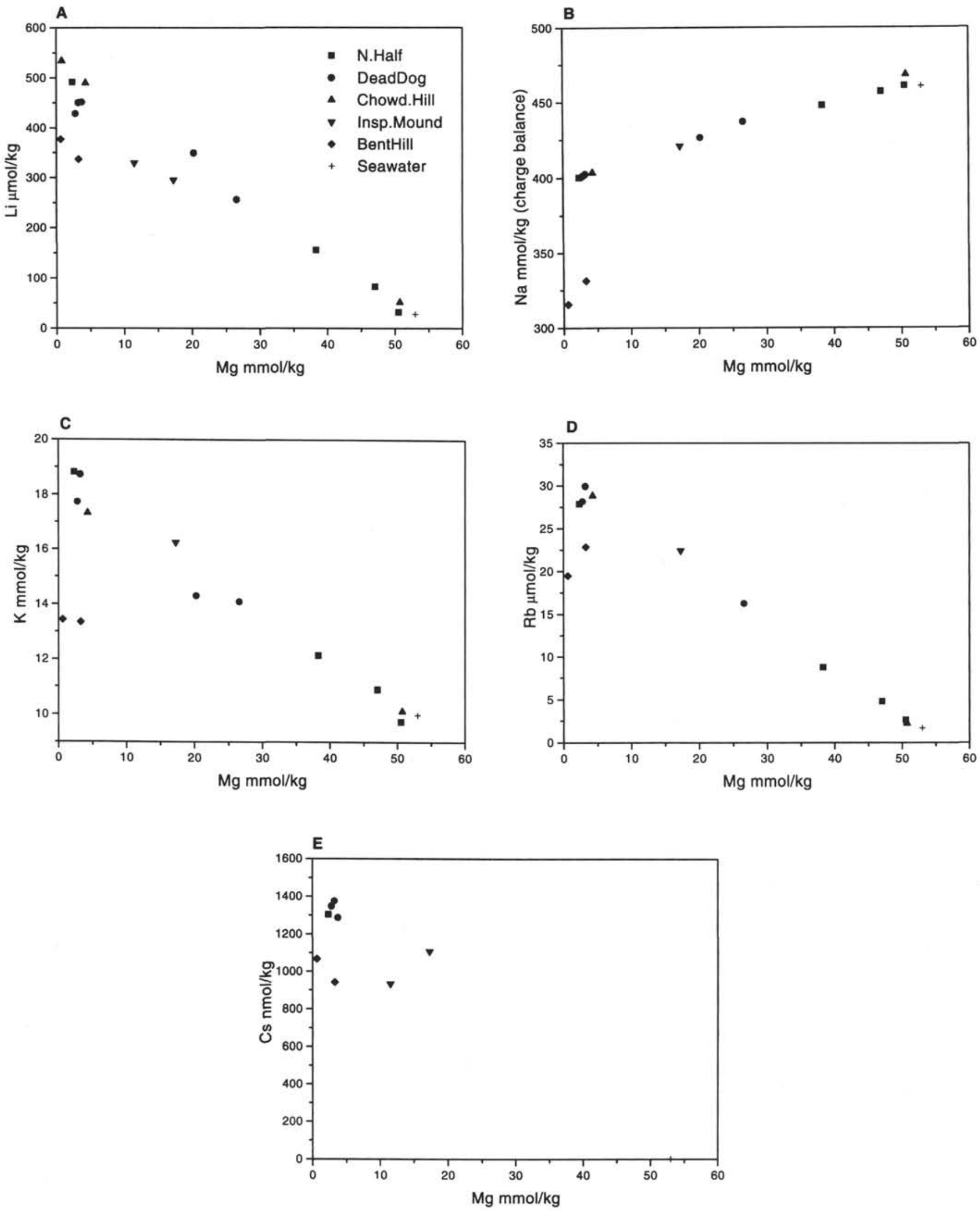

Figure 5. Alkali elements plotted vs. magnesium. A. Lithium. B. Sodium, calculated by charge balance. C. Potassium. D. Rubidium. E. Cesium. 

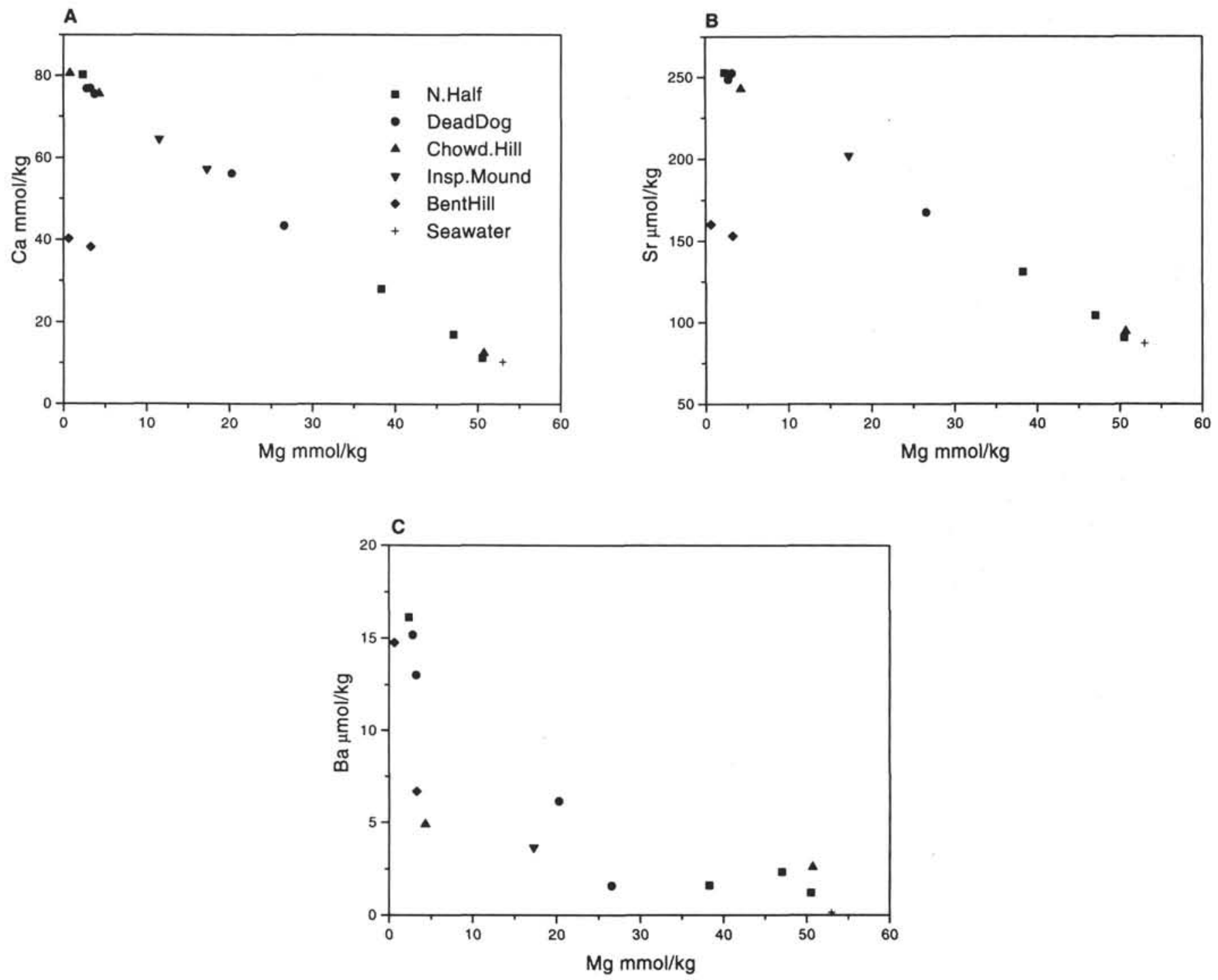

Figure 6. Alkaline Earth elements plotted vs. magnesium. A. Calcium. B. Strontium. C. Barium.

cannot be overcome by filtering because filtration prior to acidification removes most of the chalcophillic metals.

Equilibrium chemical speciation calculations using MINEQL and the database described by Tivey (1988) indicate that Middle Valley vent fluids are near saturation with magnetite and a host of metal sulfides, including bornite, chalcopyrite, chalcocite, pyrrhotite, covellite, galena, pyrite, and sphalerite.

\section{Iron}

Iron is present at relatively low concentrations in these fluids (Fig. 7). Endmembers range from $10-18 \mu \mathrm{mol} / \mathrm{kg}$ among the vents at Site 858 ; the endmember at Site 856 has $17 \mu \mathrm{mol} / \mathrm{kg}$ Fe. These concentrations are comparable to those in vent fluids from Guaymas Basin, which have similar $\mathrm{pH}$ and temperature and somewhat higher hydrogen sulfide concentrations than Middle Valley fluids. Since these fluids are rising through a large massive sulfide deposit, iron and other trace metal concentrations are probably controlled by sulfide solubility. Scatter in iron vs. magnesium data within the Site 858 area may be caused by small differences in $\mathrm{pH}$, temperature, and $\mathrm{H}_{2} \mathrm{~S}$ concentration among the fluids. (The $\mathrm{H}_{2} \mathrm{~S}$ data are not precise enough to yield information on differences in sulfide concentration among the vents.) The $\mathrm{pH}$ is distinctly lower at Site 856 than at Site 858 (5.1 vs. 5.5).

\section{Manganese}

There is little scatter in the manganese vs. magnesium plots (Fig. 7), probably because manganese does not easily precipitate from solution due to slight changes in $\mathrm{pH}$ and temperature as do $\mathrm{Fe}, \mathrm{Zn}$, and $\mathrm{Cu}$. The endmembers are $63 \mu \mathrm{mol} / \mathrm{kg}$ Mn at Site 858 and $78 \mu \mathrm{mol} / \mathrm{kg} \mathrm{Mn}$ at Site 856 . The higher Mn at Site 856 may be due to the lower $\mathrm{pH}$.

\section{Zinc}

There is some scatter in the zinc data (Fig. 7), with endmembers at Site 858 ranging from 0.9 to $1.7 \mu \mathrm{mol} / \mathrm{kg}$. The two samples from Site 856 yield an endmember of $0.7 \mu \mathrm{mol} / \mathrm{kg}$.

\section{Copper}

Considerable scatter exists in the copper data (Fig. 7), which we attribute in part to precipitation in the fluids prior to or during sampling. In two cases, exceptionally high copper concentrations (circled on Fig. 7) are attributed either to contamination or to entrainment of copper-rich particles into the sampler. The latter possibility is likely, since iron and zinc are also high in these samples, but manganese is not; this is consistent with contamination by mixed $\mathrm{Fe}-\mathrm{Cu}-\mathrm{Zn}$ sulfide 

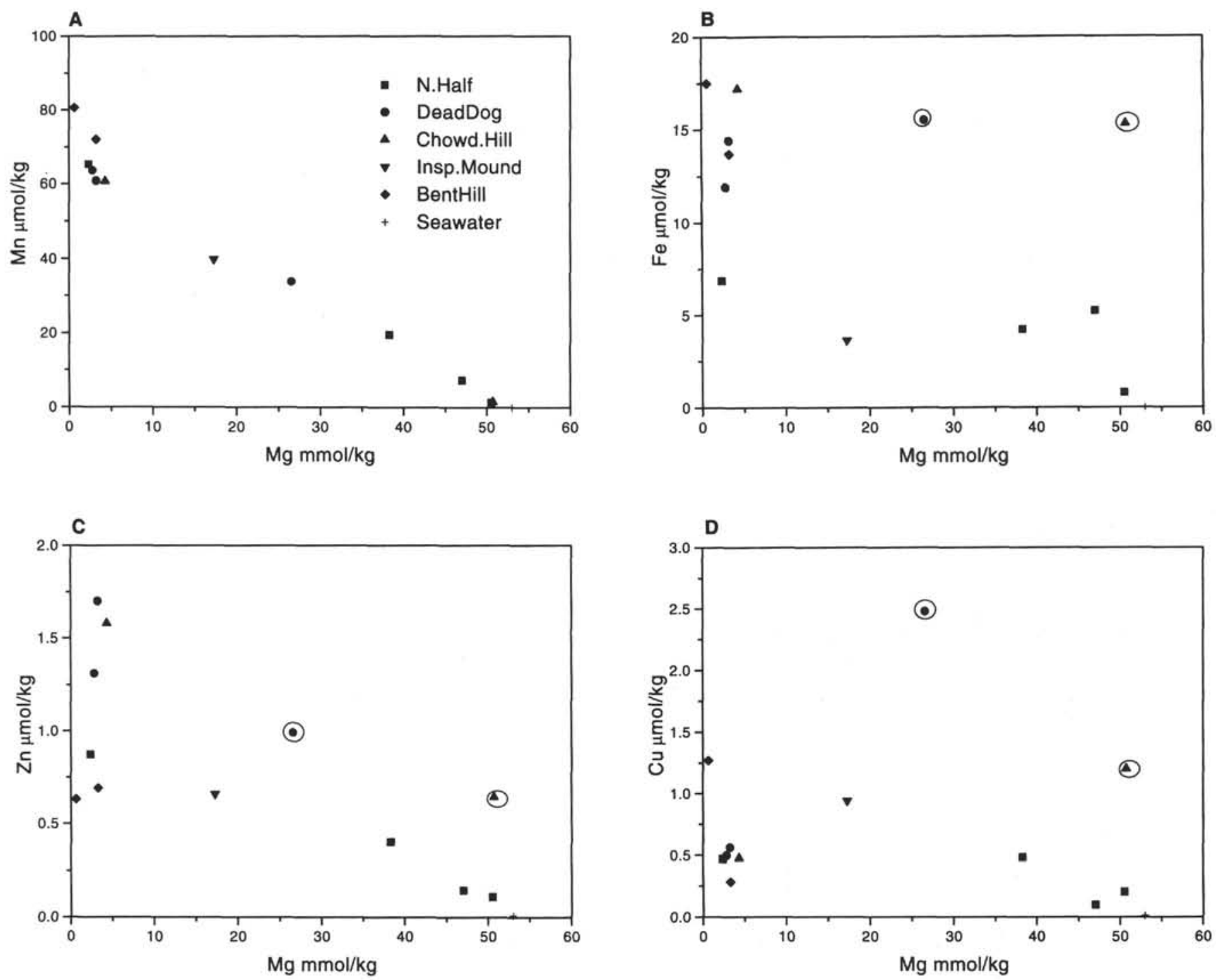

Figure 7. Transition metals plotted vs. magnesium. A. Manganese. B. Iron. C. Zinc. D. Copper. Circled data points are suspected to be contaminated with entrained $\mathrm{Fe}-\mathrm{Cu}-\mathrm{Zn}$ sulfide particles.

particles during sampling. The suspect samples were excluded in the calculation of endmember concentrations.

$\mathrm{Cu}$ endmembers range from 0.6 to $1.3 \mu \mathrm{mol} / \mathrm{kg}$ at Site 858 . The two samples collected from Site 856 agree poorly, giving a range from 0.3 to $1.3 \mu \mathrm{mol} / \mathrm{kg}$.

\section{Lead}

Endmember lead concentrations are $\sim 100 \mathrm{nmol} / \mathrm{kg}$ for Site 858 fluids ( 3 data points) and $50 \mathrm{nmol} / \mathrm{kg}$ for Site 856 fluids ( 1 data point). These concentrations are on the low end of the range for MOR vent fluids.

\section{DISCUSSION}

On the basis of sediment alteration and geochemistry, Goodfellow and Blaise (1988) proposed a model of hydrothermal fluid flow for Middle Valley sulfide deposits that involved a high-temperature fluid flowing upward in a high permeability zone at depth, then migrating radially away from the source conduit and mixing with seawaterderived pore fluids in the sediments. These authors noted that the hydrothermal fluids in Middle Valley must have been derived from reaction with basalt since the $87 \mathrm{Sr} / 86 \mathrm{Sr}$ ratios in barite $(0.7054$ $0.7060)$, gypsum $(0.70655)$, and calcite $(0.7062-0.7069)$ have a significantly basaltic character (Goodfellow et al., in press). Sulfur isotope ratios in the disseminated sulfide minerals indicate a mixture of basaltic sulfur with a large amount of seawater sulfur, which was interpreted to reflect abiotic sulfate reduction (Goodfellow and Blaise, 1988). Results from Leg 139 in Middle Valley yielded a somewhat refined model of the hydrothermal alteration structure (Davis, Mottl, Fisher, et al., 1992; Goodfellow et al., in press), whose primary features are a core of massive to semimassive sulfide surrounded by an extensive zone of highly altered sediment (chlorite-albite-quartz). This zone is in turn surrounded and overlaid by an anhydrite/pyrite-rich clay zone and finally by a carbonate-pyrite zone with at least some massive carbonate sections. These zones are thought to reflect a gradient from high-temperature to low-temperature conditions surrounding the hydrothermal upflow zone.

Our vent fluid chemistry data are in general agreement with the above model and offer some insights into the origin of fluids currently venting at Middle Valley. Overall, the chemical compositions indicate a strong influence of basalt-fluid interaction, overprinted to some degree by reactions within the sediment column. 


\section{Reaction Zone Conditions}

Middle Valley fluids from Site 858 have the highest calcium concentration of any MOR vent fluids except those with the highest chlorinity $\left(>200 \%\right.$ of seawater $\left.\mathrm{Cl}^{-}\right)$from the southern Juan de Fuca Ridge (Von Damm and Bischoff, 1987). Factors that can lead to high calcium levels in solution are (1) high chlorinities (Seyfried et al., 1991); (2) dissolution of calcite by acidic hydrothermal fluids; and (3) basalt-seawater interaction at low temperatures (Seyfried, 1987; Berndt et al., 1989). Clearly, high chlorinity is not responsible for the high calcium levels, and the data rule out dissolution of calcite for several reasons. Based on calculations with MINEQL, Middle Valley vent fluids are considerably undersaturated with respect to calcite at in-situ temperature conditions, so calcite buffering is not indicated. Furthermore, biogenic calcite has largely been removed from the high-temperature upflow zone (Goodfellow et al., in press). The data on the distribution of hydrothermal calcite in Middle Valley and its $\mathrm{Sr}$ isotope signature indicate that calcite probably forms when calciumrich hydrothermal solutions mix with alkaline pore waters. Original biogenic calcite in the sediments would have a strontium isotope signature close to that of seawater.

Based on strontium isotope ratios, we infer that the calcium is primarily derived from a basaltic source. ${ }^{87} \mathrm{Sr} /{ }^{86} \mathrm{Sr}$ ratios in Middle Valley vent fluids are $\sim 0.7043$, just slightly higher than the reported range of 0.7028 to 0.7041 for basalt-hosted MOR hydrothermal fluids (Von Damm, 1990, and references therein) and significantly lower than the ${ }^{87} \mathrm{Sr} /{ }^{86} \mathrm{Sr}$ ratios of $\sim 0.7066$ in Middle Valley calcite from sediment cores or the ratios in bulk sediment of $\geq 0.708$ (Goodfellow and Blaise, 1988; Goodfellow et al., in press). ${ }^{87} \mathrm{Sr} /{ }^{86} \mathrm{Sr}$ ratios in vent fluids from Guaymas Basin range from 0.7052 to 0.7058 (Von Damm et al., 1985) and ${ }^{87} \mathrm{Sr} /{ }^{86} \mathrm{Sr}$ ratios in hydrothermal fluids from Escanaba Trough are 0.7099, higher than seawater (Campbell et al., in press). The $\mathrm{Sr}$ in Middle Valley vent fluids is predominantly basaltic, showing that little $\mathrm{Sr}$ (and by inference, $\mathrm{Ca}$ ) has been derived from the approximately $250 \mathrm{~m}$ of hemipelagic and turbiditic sediment between the seafloor and the basaltic basement. This is in agreement with the prediction of Goodfellow and Blaise (1988) that high-temperature hydrothermal fluids from Middle Valley would be dominated by basalt-seawater interaction, modified somewhat by reaction with clay minerals in the sediment column. The implication is that the reaction zone for the high-temperature vents is below the basalt-sediment interface and that the vent fluids are not greatly influenced by entrainment or lateral advection of pore fluids beneath relatively impermeable layers.

A possible alternative to the hypothesis that presently venting fluids do not extract significant levels of calcium from the sediment column is that the entire sediment column in the upflow zone is so highly altered that it now has a nearly basaltic strontium isotope signature. However, the lowest ${ }^{87} \mathrm{Sr} /{ }^{86} \mathrm{Sr}$ ratios in altered sediments reported by Goodfellow et al. (in press) are $>0.707$, so that we consider this alternative hypothesis to be unlikely.

While calcium is highly enriched, sodium is depleted in the Middle Valley fluids relative to seawater levels (Table 3 ). The high $\mathrm{Ca}$ and low $\mathrm{Na} / \mathrm{Cl}$ ratios of Site 858 fluids may be due to the formation of sodiumrich alteration phases (e.g., albite). Relatively low-temperature $\left(<325^{\circ} \mathrm{C}\right)$ basalt alteration favors dissolution of hydrous calcium-bearing silicates and formation of a sodium-rich phase such as albite (Seyfried, 1987; Berndt et al., 1989). Sediment mineralogy and thermodynamic calculations also suggest that albite precipitation may occur. Minor albite is present in hydrothermally altered sediment cores from Middle Valley (Goodfellow et al., in press). Calculations of mineral saturation were performed using the chemical speciation predicted by MINEQL and the equilibrium constants derived from SUPCRT92 (Johnson et al., 1992) for albite hydrolysis and conversion of anorthite to albite + clinozoisite. Assuming that the dissolved aluminum concentration is $10 \mu \mathrm{mol} / \mathrm{kg}$ (the average value reported for vent fluids by Von Damm, $1990)$, albite precipitation is highly favored $(\log Q / K>20)$. The alumi- num-conservative reaction converting anorthite to albite + clinozoisite is near equilibrium $(\log \mathrm{Q} / \mathrm{K} \sim-2)$.

$\mathrm{The} \mathrm{Ca} / \mathrm{Cl}$ ratio of Site 856 fluids is significantly lower than at Site 858 , indicating that the lower chlorinity at Site 856 is not the direct, immediate result of phase separation of a common source fluid, since the low-chlorinity and high-chlorinity fluids would have similar element/chloride ratios (Butterfield et al., 1990). However, since the vent sites are several kilometers apart, it is unlikely that the fluids would share a common reaction zone. The lower Ca levels may reflect higher reaction zone temperatures at Site 856.

The lowest $\mathrm{Na} / \mathrm{Cl}$ ratio of any sediment-starved MOR vent fluids is 0.742 at Pipe Organ vent on the northern Cleft Segment, where the high chlorinity $(1245 \mathrm{mmol} / \mathrm{kg})$ leads to enhanced calcium solubility and favors the formation of albite (Butterfield and Massoth, in press).

Low $\mathrm{Sr} / \mathrm{Ca}$ ratios in Middle Valley vent fluids add support to the hypothesis that the fluids have precipitated sodium-rich plagioclase with a high $\mathrm{Sr} / \mathrm{Ca}$ ratio (Blundy and Wood, 1991; Palmer, 1992). The best explanation for the high levels of calcium in Site 858 hydrothermal fluids is equilibration with basalt at temperatures $\leq 325^{\circ} \mathrm{C}$. Under these conditions, hydrous calcium silicate minerals are highly soluble (Seyfried, 1987).

\section{Comparison of Middle Valley and Other Seafloor Hydrothermal Systems}

Important differences exist in fluid chemistry and geologic environment between Middle Valley and the two other sedimented MOR hydrothermal systems studied to date, Guaymas Basin in the Gulf of California and Escanaba Trough on Gorda Ridge. Some aspects of sediment compositions are compared in Table 5. Like Middle Valley, Guaymas Basin has a mixture of hemipelagic and turbiditic sediments, but the biogenic component at Guaymas is dominated by diatoms, which account for up to $70 \%$ of the sediment volume in the surface layers (Gieskes et al., 1988). The biogenic component in surface sediments at Middle Valley accounts for only a few percent of the total volume and is dominated by forams and radiolaria, with a minor diatom component (Goodfellow and Blaise, 1988). Typical total organic carbon (TOC) contents in the surface sediments of Guaymas Basin are 4 to 5 weight percent (wt\%), decreasing to 1.5 to $2.5 \mathrm{wt} \%$ below $10 \mathrm{~cm}$ (Gieskes et al., 1988). TOC levels in Leg 139 cores typically do not exceed $0.5 \mathrm{wt} \%$ (Davis, Mottl, Fisher, et al., 1992). The sediment composition at Escanaba Trough is similar in many respects to the sediment composition at Middle Valley (Table 5). We would expect that, for a similar degree of water/sediment interaction, the components derived from reaction with organic material (e.g., ammonia and alkalinity) should be more enriched in Guaymas Basin fluids than in fluids from Escanaba or Middle Valley, which is the case.

The vent fluids from the three sedimented systems considered here all differ from unsedimented MOR fluids and differ substantially among themselves (Table 6) in terms of major element composition and constituents derived from sedimentary and organic material. The trends in alkalinity and ammonia (Guaymas Basin > Escanaba > Middle Valley) can be attributed to the parallel trend in calcium carbonate and organic contents of the sediments, and possibly to differences in water/sediment (W/S) ratio and the extent of sediment alteration in the upflow zone. (Apparent W/S ratio and extent of alteration of the sediment column may be directly related if fluid constituents used to estimate W/S ratios become depleted in the sediments.) The trend of increasing alkali concentration in the vent fluids (Middle Valley < Guaymas < Escanaba) indicates a parallel trend in the W/S ratio (i.e., decreasing W/S ratio from Middle Valley to Escanaba). Bromide and iodide are present at similar concentrations in the three sedimented systems, in spite of differences in the amount of organic matter involved. Quantitative data on bromide and iodide in Middle Valley sediments are needed for a comparative investigation of halide systematics. 
Table 5. Comparison of Middle Valley, Guaymas Basin, and Escanaba Trough sediment composition.

\begin{tabular}{lccc}
\hline Constituent & $\begin{array}{c}\text { Middle } \\
\text { Valley }\end{array}$ & $\begin{array}{c}\text { Escanaba } \\
\text { Trough }\end{array}$ & $\begin{array}{c}\text { Guaymas } \\
\text { Basin }\end{array}$ \\
\hline Organic carbon & $0.3-0.8$ & $0.3-0.5$ & $2-4$ \\
Sulfur & $0.05-0.3$ & $0.08-0.2$ & $1-2$ \\
CaCO $_{3}$ & $0.2-2$ & $1-3$ & $10-15$ \\
Opaline silica & $2-12$ & $5-14$ & $30-50$ \\
Detrital clay & $55-70$ & $42-65$ & $30-45$ \\
\end{tabular}

Notes: Compositions in weight percent. Data sources, Middle Valley: Davis, Mottl, Fisher, et al., 1992; Goodfellow and Blaise, 1988. Data sources, Escanaba Trough and Guaymas Basin: Campbell et al., in press, and references therein.

\section{Alkali Systematics in Sedimented and Unsedimented Seafloor Hydrothermal Systems}

When the available alkali data from all seafloor hydrothermal systems are considered (You et al., in press), two clear trends emerge, one formed by the basalt-hosted, or sediment-starved hydrothermal areas and the other by sediment-covered hydrothermal areas (Fig. 8). The trace alkalies are highly enriched in hydrothermal fluids and their ratios can yield information about sources. Lithium may be considered an indicator of the water/rock ratio in both types of fluids, with high $\mathrm{Li}$ levels resulting from low water/rock ratios. While lithium is thought to be highly mobile and efficiently extracted from basalt at temperatures $>300^{\circ} \mathrm{C}$, it is possible that lithium may be removed from solution into alteration phases under the intermediate temperature conditions of some sediment-covered hydrothermal systems (Berger et al., 1988). The ionic radii of $\mathrm{Li}$ and $\mathrm{Na}$ are similar enough so that $\mathrm{Li}$ may substitute for $\mathrm{Na}$ in some secondary minerals, whereas the ionic radii of $\mathrm{Rb}$ and $\mathrm{Cs}$ are too large to substitute for $\mathrm{Na}$. This may account for the high levels of $\mathrm{Rb}$ and $\mathrm{Cs}$ accompanied by moderate levels of $\mathrm{Li}$, and fits with the overall chemistry that implies that $\mathrm{Na}$-rich phases are precipitated from solution.

Sediments have higher levels of $\mathrm{Rb}$ and $\mathrm{Cs}$ than basalt. For example, unaltered Middle Valley sediment has $\sim 60 \mathrm{ppm} \mathrm{Rb}$ (Davis, Mottl, Fisher, et al., 1992) vs. an average of $1.8 \mathrm{ppm}$ for fresh submarine basalt (Hart, 1969). Cs concentrations in fresh basalt are $\sim 0.024 \mathrm{ppm}$ (Hart, 1969) and Rb/Cs ratios are lower in sediments than in basalt (Ben Othman et al., 1989). Sediment-hosted hydrothermal fluids have considerably higher levels of $\mathrm{Rb}$ and $\mathrm{Cs}$, higher $\mathrm{Rb} / \mathrm{Li}$ ratios, and lower $\mathrm{Rb} / \mathrm{Cs}$ ratios than sediment-starved hydrothermal fluids, reflecting the influence of the sedimentary source. The literature is divided on whether alkalies in hydrothermal fluids are so mobile that they are controlled primarily by the source characteristics (Palmer and Edmond, 1989) (i.e., ratios fixed by dissolution of the source) or whether distribution between solution and secondary minerals controls concentrations and ratios in the fluids (Berger et al., 1988).

Among the sedimented systems, Middle Valley vent fluids have the lowest levels of all trace alkalis, the highest $\mathrm{Rb} / \mathrm{Cs}$ ratio, and a higher lithium-derived water/rock ratio. The alkali systematics of Middle Valley fluids are consistent with some fluid-sediment interaction, but to a lesser degree than are fluids from Guaymas Basin and Escanaba Trough. For model calculations run at $260^{\circ} \mathrm{C}$, Berger et al. (1988) report that $\mathrm{Rb}$ and Cs in solution were buffered by the secondary mineral assemblage at concentrations much lower and at a $\mathrm{Rb} / \mathrm{Cs}$ molar ratio about an order of magnitude higher than that measured at Middle Valley and other sedimented hydrothermal systems, so it appears that the secondary minerals in their experiments (chlorite, smectite, zeolite) are not controlling alkali concentrations in MOR hydrothermal fluids, even under temperature conditions similar to those of the experiments. Experimental evidence suggests that decreasing temperature favors increased uptake by secondary phases (Berger et al., 1988). That Escanaba Trough vent fluids are cooler yet have much higher alkali concentrations than Middle Valley vent fluids is further evidence against control of alkalies by secondary mineral uptake.

In general, $\mathrm{Rb} / \mathrm{Cs}$ and $\mathrm{Li} / \mathrm{Rb}$ ratios in fluids from unsedimented hydrothermal systems resemble the ratios in fresh basalt (with some scatter), while $\mathrm{Rb} / \mathrm{Cs}$ and $\mathrm{Li} / \mathrm{Rb}$ ratios in fluids from sedimented systems resemble the ratios in pelagic sediment (Fig. 8). The major exception is the volcanic-hosted Endeavour hydrothermal system, which clearly shows some influence of sedimentary involvement in the fluid chemistry. Li-Rb-Cs systematics in hydrothermal fluids appear to be dominated largely by the source characteristics rather than by equilibrium between solution and secondary minerals.

\section{Relation of Vent Fluids to Pore Fluids}

In proposed models of hydrothermal circulation through sediments at Middle Valley (Goodfellow and Blaise, 1988; Davis, Mottl, Fisher, et al., 1992; Goodfellow et al., in press), high-temperature fluids ascend through an upflow zone and percolate outward into the sediment column, feeding and interacting with sediment pore fluids. As described above, the measured chemistry of the high-temperature vent fluids is in general agreement with such a model if the reaction

Table 6. Comparison of Middle Valley, Guaymas Basin, and Escanaba Trough vent fluid composition.

\begin{tabular}{|c|c|c|c|c|c|c|}
\hline \multirow[b]{2}{*}{ Constituent } & \multirow[b]{2}{*}{ Unit } & \multicolumn{2}{|c|}{ Middle Valley } & \multicolumn{2}{|c|}{ Guaymas Basin } & \multirow[b]{2}{*}{ Escanaba Trough } \\
\hline & & Dead Dog & Bent Hill & S. Field & E. Hill & \\
\hline Temperature & ${ }^{\circ} \mathrm{C}$ & $180-275$ & 265 & $250-308$ & 290 & $108-217$ \\
\hline $\mathrm{pH}$ & & 5.5 & 5.13 & 5.9 & 5.9 & 5.4 \\
\hline Alkalinity & $\mathrm{mmol} / \mathrm{kg}$ & $1.4-2.0$ & 1.45 & 9.6 & 8.9 & 3.1 \\
\hline $\mathrm{Cl}$ & $\mathrm{mmol} / \mathrm{kg}$ & 578 & 412 & $581-604$ & 603 & 668 \\
\hline $\mathrm{Br} / \mathrm{Cl}$ & $\mu \mathrm{mol} / \mathrm{mmol}$ & 1.85 & 1.87 & $1.8-1.85$ & 1.76 & 1.76 \\
\hline B & $\mu \mathrm{mol} / \mathrm{kg}$ & 1730 & 1600 & $1600-1680$ & 1550 & $1710-2160$ \\
\hline $\mathrm{Si}$ & $\mathrm{mmol} / \mathrm{kg}$ & $9.7-10.6$ & 10.3 & $12-13.5$ & 13.8 & $5.6-6.9$ \\
\hline $\mathrm{Li}$ & $\mu \mathrm{mol} / \mathrm{kg}$ & $430-550$ & 370 & 993 & $849^{150}$ & 1286 \\
\hline $\mathrm{Na} / \mathrm{Cl}$ & & 0.689 & 0.765 & 0.800 & 0.809 & 0.838 \\
\hline $\mathrm{Rb}$ & $\mu \mathrm{mol} / \mathrm{kg}$ & 31 & 22.5 & 60 & 52 & $80-105$ \\
\hline Cs & $\mu \mathrm{mol} / \mathrm{kg}$ & 1.4 & 1.0 & $5.5-6.0$ & 5.2 & $6.0-7.7$ \\
\hline $\mathrm{Ca}$ & $\mathrm{mmol} / \mathrm{kg}$ & 81 & 40 & 27.7 & 33.8 & 33.4 \\
\hline $\mathrm{Sr}$ & umol/kg & 257 & 162 & 158 & 191 & 209 \\
\hline${ }^{87} \mathrm{Sr} /{ }^{86} \mathrm{Sr}$ & & 0.7042 & 0.7044 & 0.7059 & 0.7052 & 0.7099 \\
\hline $\mathrm{Sr} / \mathrm{Ca}$ & $\mu \mathrm{mol} / \mathrm{mmol}$ & 3.17 & 4.05 & 5.7 & 5.65 & 6.25 \\
\hline I & $\mu \mathrm{mol} / \mathrm{kg}$ & 110 & 85 & $80-83$ & 65 & 99 \\
\hline
\end{tabular}

Note: Data sources, Middle Valley: this study; Escanaba Trough: Campbell et al., in press; Guaymas Basin: Von Damm et al., 1985; Campbell and Edmond, 1989. 

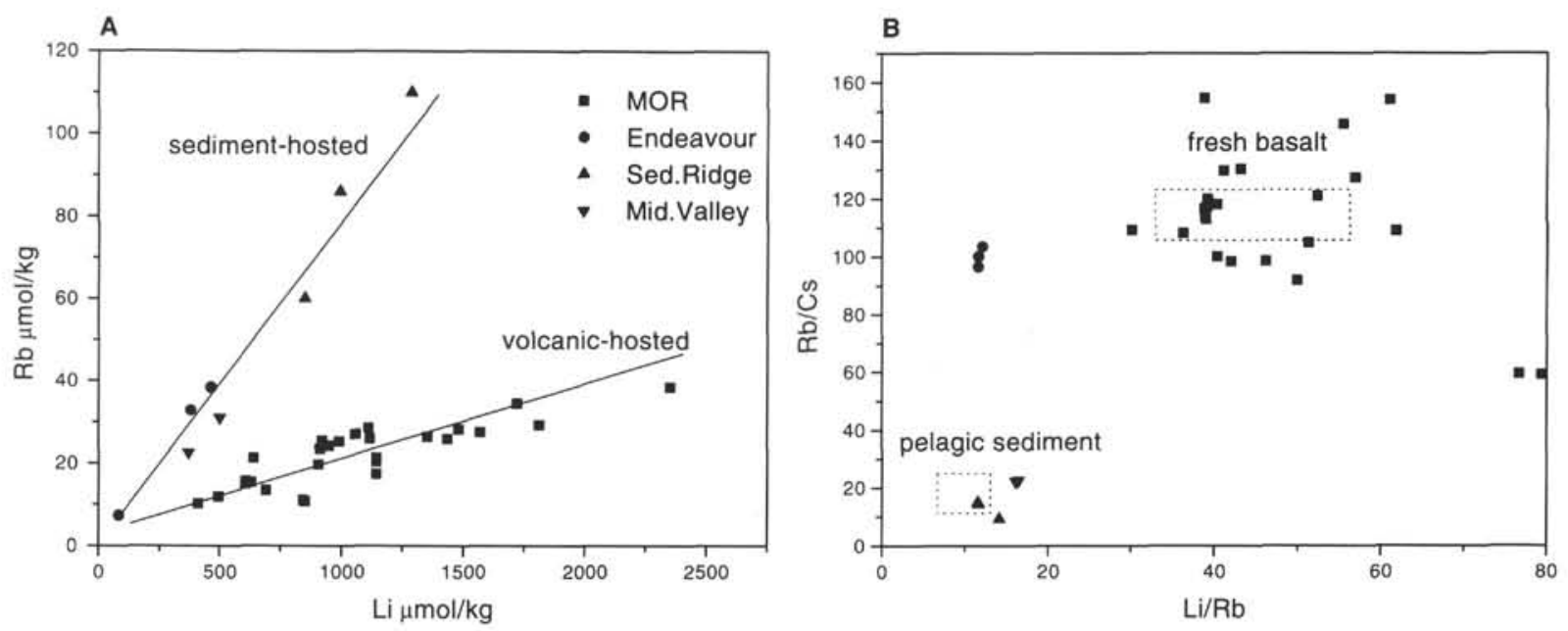

Figure 8. Alkali systematics in hydrothermal fluids from sedimented and unsedimented mid-ocean ridge sites. A. Rubidium vs. lithium. With the exception of the Endeavour Ridge, all volcanic-hosted MOR fluids lie near a single trend. High-chlorinity fluids from the southern Juan de Fuca Ridge have the highest concentrations of $\mathrm{Rb}$ and $\mathrm{Li}$. Sediment-hosted systems form a separate trend, and Middle Valley fluids have the lowest concentrations of $\mathrm{Rb}$ and $\mathrm{Li}$ of the sedimented systems. B. $\mathrm{Rb} / \mathrm{Cs}$ vs. Li/Rb molar ratios. The reported ranges of the ratios of these elements in fresh basalt (Hart, 1969; Ryan and Langmuir, 1987) and pelagic sediment (Ben Othman et al., 1989; Heinrichs et al., 1980) are indicated by the dashed rectangles. Fluids from sedimented hydrothermal systems have ratios similar to the sedimentary source, while sediment-starved hydrothermal fluids have ratios that cluster near the ratios of fresh basalt. Vent fluid data from Palmer and Edmond (1989), except Butterfield et al., in press (Endeavour) and C.-F. You, in press.

zone is located in the basaltic basement below the sediment column. The interactions of high-temperature fluid with sediment are confined to the upflow zone in this type of model.

Given the proximity of the sampled vent fluids to the cores taken during Leg 139, it is notable that the chlorinity of the vent fluids ( 580 $\mathrm{mmol} / \mathrm{kg}$ at Site 858 ) does not match the chlorinity of the pore fluids. Pore fluids in the upper $30 \mathrm{~m}$ in Holes $858 \mathrm{~B}$ and 858D (Fig. 1), which have the lowest sulfate and highest silica levels of pore fluids less than $150 \mathrm{mbsf}$, are significantly higher in chlorinity ( 600 to $660 \mathrm{mmol} / \mathrm{kg}$ ) than the vented fluids. On the basis of chlorinity, the closest match to the Site 858 vent fluids is from core taken at Hole $858 \mathrm{~A}(>100 \mathrm{~m}$ away from the apparent edge of the sulfide deposit; Fig. 1), at depths greater than $200 \mathrm{~m}$. Furthermore, no pore fluids from any core taken during Leg 139 are significantly depleted in chlorinity, as is the case for Site 856 vent fluids. The Site 858 Shipboard Scientific Party (Davis, Mottl, Fisher, et al., 1992) reported isolated chlorinity maxima of 620 and $660 \mathrm{mmol} / \mathrm{kg}$ in cores taken within the vent field and interpreted these to result from lateral flow of pore fluids beneath relatively impermeable sediment layers.

Conclusions to be drawn from these observations are: (1) the measured pore fluids do not supply the high-temperature vent fluids, consistent with the model of a high-temperature fluid ascending from depth and migrating outward; (2) if the migrating pore fluids are supplied by the ascending high-temperature fluids, then either continued reaction of the fluids with sediments to raise the chlorinity (i.e., hydration) or temporal variability of the high-temperature fluid composition is required. Temporal variability in the chlorinity of venting fluids was also proposed for Guaymas Basin (Peter and Scott, 1988). Alternatively, a distinct source of fluid, which is not presently venting, may feed the laterally migrating pore fluids.

\section{Variation Within the Dead Dog Vent Field}

The measured temperatures range from $184^{\circ} \mathrm{C}$ to $276^{\circ} \mathrm{C}$ in the high-temperature vents at Site 858, but the variation in major element composition is small for most elements. With the exception of the diluted samples and one sample from Heineken Hollow, the mean endmember chlorinity of all samples (mean of individually extrapolated zero-magnesium endmembers) from Site 858 is $578.8 \pm 3.7$ $\mathrm{mmol} / \mathrm{kg}$. The single sample from Heineken Hollow $(90 \%$ ambient seawater) yields a slightly lower endmember chlorinity of $563 \mathrm{mmol} /$ $\mathrm{kg}$. In samples collected at Site 858 , lithium shows the largest variation in endmember concentration of the minor elements we measured, but there is no clear trend with location or temperature. Boron concentrations and alkalinities are slightly lower in the northern half of the Site 858 field (East Hill and Central Site), possibly reflecting less fluid-sediment interaction in the fluids with lower boron. The highest alkalinities and boron concentrations are from Chowder Hill and Inspired Mound. Among the trace metals, manganese concentrations all lie on a single trend, and zinc appears to be highest in the fluids from Dead Dog Hill. The data for $\mathrm{Cu}$ and $\mathrm{Fe}$ have too much scatter to draw conclusions about differences among vents. Except for the north-south difference in boron concentration, there are no apparent systematic trends of any element with location or temperature.

\section{Time Series}

The few samples recovered in 1991 and 1992 were diluted with ambient seawater during sampling, but do allow a comparison with the 1990 data. The 1991 chloride data do not fit a linear dilution curve and cannot be extrapolated to a reliable endmember. The 1991 endmembers for $\mathrm{Si}, \mathrm{Ca}, \mathrm{K}, \mathrm{B}, \mathrm{Sr}$, and $\mathrm{Li}$ agree with the 1990 data to within the uncertainty of the extrapolations.

\section{Low Chlorinity at Site $\mathbf{8 5 6}$}

Probably the most remarkable characteristic of the vent fluids from Site 856 (Bent Hill) is their low chlorinity $(412 \mathrm{mmol} / \mathrm{kg}$, or $76 \%$ of seawater). The slightly elevated chlorinities in the Site 858 vent fluids from Middle Valley, as in vent fluids from Escanaba Trough and Guaymas Basin, can conceivably be accounted for by removal of water into hydrous alteration phases. The vent fluids from Site 856 are the only fluids sampled from a sedimented MOR that have chlorinity significantly lower than seawater. It is unreasonable to try to explain the low chlorinity by sediment dehydration when the tendency at all other sedimented sites is for hydration under similar conditions. Furthermore, the $\mathrm{Br} / \mathrm{Cl}$ ratios in vent fluids from Site 856 and Site 858 are virtually identical, so fluid reactions involving precipitation of a chloride-bearing mineral are ruled out because they would produce fractionation of bromide from chloride. The magni- 
tude of the chloride depletion, the higher levels of $\mathrm{CO}_{2}$ (B.E. Taylor, pers. comm., 1993), and the correlation of other elements (e.g., K, Li, $\mathrm{Ca}, \mathrm{Sr}$ ) with chlorinity suggest that the low-chlorinity vent fluids at Site 856 may be slightly enriched in a vapor phase produced by phase separation. The measured temperature is over $100^{\circ} \mathrm{C}$ below the boiling temperature at local seafloor pressure, and quartz geothermometry is consistent with $265^{\circ} \mathrm{C}$ temperatures in the upflow zone, so phase separation would require that the fluids have both cooled substantially and re-equilibrated after phase separation took place. We can only speculate that phase separation occurred in the crust during a previous high-temperature reaction period that resulted in vaporenriched fluids accumulating beneath the Bent Hill site. Clearly, the limited data are only suggestive, but other explanations for chloride depletion are even more speculative.

Fluids from Sites 856 and 858 differ in chlorinity and in terms of their major element chemistry, though some elemental ratios are similar in the two sites. Site 856 has much lower $\mathrm{Ca}$, an $\mathrm{Na} / \mathrm{Cl}$ ratio closer to the seawater ratio, and a higher $\mathrm{Sr} / \mathrm{Ca}$ ratio, all of which indicate less precipitation of an Na-rich mineral from solution at Site 856. If fluids from the two areas are derived by phase separation of a common (or similar) source fluid, these differences could be explained in part by the different chlorinities of the two fluids, since higher chlorinity favors enhanced solubility of calcium relative to sodium in solution. Lower calcium levels at Site 856 may also be related to higher temperatures in the reaction zone (Seyfried, 1987).

Trace metal levels in fluids from both sites are similar, probably because the temperatures are similar and trace metal levels in solution are buffered by the presence of a similar assemblage of iron oxides and metal sulfides at both sites.

\section{CONCLUSIONS}

The chemistry of vent fluids from Site 858 appears to be largely controlled by basalt-seawater interaction at relatively low temperatures $\left(\leq 325^{\circ} \mathrm{C}\right)$. Evidence in support of this includes high calcium levels combined with a basaltic strontium isotope signature, and low alkalinities. Low $\mathrm{Na} / \mathrm{Ca}, \mathrm{Na} / \mathrm{Cl}$, and $\mathrm{Sr} / \mathrm{Ca}$ ratios indicate that the fluids have formed Na-rich alteration phases.

Vent fluids from the single chimney near Bent Hill have a chlorinity of only $76 \%$ that of seawater. Phase separation with segregation of vapor from a brine phase is the only feasible mechanism to generate a fluid with a chlorinity this low.

Based on equilibrium speciation calculations, the fluids are near saturation with respect to magnetite and a host of metal sulfides, but are highly undersaturated with respect to calcite. Calcite observed in Middle Valley sediments probably forms when calcium-rich hydrothermal fluids mix with high-alkalinity pore fluids.

Alkali systematics, and ammonia and boron concentrations in Middle Valley fluids are characteristic of sedimented hydrothermal systems. However, the magnitude of the sedimentary signal in Middle Valley fluids is not as strong as at Guaymas Basin or Escanaba Trough, as evidenced in particular by the near-basaltic strontium isotope signature at Middle Valley. This is probably due to a combination of lower levels of organic material in unaltered sediments at Middle Valley, other differences in sediment composition, and a slightly higher water/sediment ratio at Middle Valley. Within the bounds of a limited dataset, Middle Valley vents the most basalt-dominated fluids of the three sedimented MOR hydrothermal systems studied to date.

\section{ACKNOWLEDGMENTS}

We thank the Alvin Deep Submergence Group for their efforts in obtaining vent fluid samples, Vee Atnip for shipboard sample handling and analysis, Gary Massoth at PMEL for sharing iron and manganese data, Bruce Nelson at the University of Washington Department of Geological Sciences for providing mass spectrometer facilities for strontium isotope measurements, Melinda Brockington and Kevin Roe for assistance with fluid analysis, Peter Saccocia for calculation of equilibrium constants, and Wayne Goodfellow and co-authors for providing a preprint of their manuscript in press. Kevin Roe's expertise in the laboratory was invaluable, particularly in developing a method for cesium analysis. A. Magenheim and J. Bischoff provided helpful reviews. This is PMEL contribution number 1447 and JISAO contribution number 227.

\section{REFERENCES*}

Ames, D.E., Franklin, J.M., and Hannington, M.H., in press. Mineralogy and geochemistry of active and inactive chimneys and massive sulfide, Middle Valley, northern Juan de Fuca Ridge: an evolving hydrothermal system. Can. Mineral.

Ben Othman, D., White, W.M., and Patchett, J., 1989. The geochemistry of marine sediments, island arc magma genesis and crust-mantle recycling. Earth Planet. Sci. Lett., 94:1-21.

Berger, G., Schott, J., and Guy, C., 1988. Behavior of Li, Rb, and Cs during basalt glass and olivine dissolution and chlorite, smectite and zeolite precipitation from seawater: experimental investigations and modelization between $50^{\circ} \mathrm{C}$ and $300^{\circ} \mathrm{C}$. Chem. Geol., 71:297-312.

Berndt, M.E., Seyfried, W.E., Jr., and Janecky, D.R., 1989. Plagioclase and epidote buffering of cation ratios in mid-ocean ridge hydrothermal fluids: experimental results in and near the supercritical region. Geochim. Cosmochim. Acta, 53:2283-2300.

Bischoff, J.L., and Dickson, F.W., 1975. Seawater-basalt interaction at $200^{\circ} \mathrm{C}$ and 500 bars: implications for origin of seafloor heavy metal deposits and regulation of seawater chemistry. Earth Planet. Sci. Lett., 25:385-397.

Blundy, J.D., and Wood, B.J., 1991. Crystal-chemical controls on the partition of $\mathrm{Sr}$ and $\mathrm{Ba}$ between plagioclase feldspar, silicate melts and hydrothermal solutions. Geochim. Cosmochim. Acta, 55:193-209.

Butterfield, D.A., and Massoth, G.J., in press. Geochemistry of North Cleft Segment vent fluids: temporal changes in chlorinity and their possible relation to recent volcanism. J. Geophys. Res.

Butterfield, D.A., Massoth, G.J., McDuff, R.E., Lupton, J.E., and Lilley, M.D., 1990. Geochemistry of hydrothermal fluids from Axial Seamount Hydrothermal Emissions Study vent field, Juan de Fuca: subseafloor boiling and subsequent fluid-rock interaction. J. Geophys. Res., 95:12895-12921.

Butterfield, D.A., McDuff, R.E., Mottl, M.J., Lilley, M.D., Massoth, G.J., and Lupton, J.E., in press. Gradients in the composition of hydrothermal fluids from the Endeavour Segment vent field: phase separation and brine loss. J. Geophys. Res.

Campbell, A.C., Bowers, T.S., Measures, C.I., Falkner, K.K., Khadem, M. and Edmond, J.M., 1988. A time series of vent fluid compositions from $21^{\circ}$ N, East Pacific Rise $(1979,1981,1985)$ and the Guaymas Basin, Gulf of California (1982, 1985). J. Geophys. Res., 93:4537-4550.

Campbell, A.C., and Edmond, J.M., 1989. Halide systematics of submarine hydrothermal vents. Nature, 342:168-170.

Campbell, A.C., German, C.R., Palmer, M.R., Gamo, T., and Edmond, J.M., in press. Chemistry of hydrothermal fluids from the Escanaba Trough, Gorda Ridge. U.S. Geol. Surv. Bull.

Davis, E.E., Goodfellow, W.D., Bornhold, B.D., Adshead, J., Blaise, B. Villinger, H., and Le Cheminant, G.M., 1987. Massive sulfides in a sedimented rift valley, northern Juan de Fuca Ridge. Earth Planet. Sci. Lett., 82:49-61.

Davis, E.E., Mottl, M.J., Fisher, A.T., et al., 1992. Proc. ODP, Init. Repts., 139: College Station, TX (Ocean Drilling Program).

Embley, R.W., et al., 1992. Experiences with a remotely operated vehicle on the Juan de Fuca Ridge: a joint Canadian/US expedition. Eos, 73:253.

Gieskes, J.M., Simoneit, B.R.T., Brown, T., Shaw, T., Wang, Y.-C., and Magenheim, A., 1988. Hydrothermal fluids and petroleum in surface sediments of Guaymas Basin, Gulf of California: a case study. Can. Mineral., 26:589-602.

Goodfellow, W.D., and Blaise, B., 1988. Sulphide formation and hydrothermal alteration of hemipelagic sediment in Middle Valley, northern Juan de Fuca Ridge. Can. Mineral., 26:675-696.

Goodfellow, W.D., Grapes, K., Cameron, B., and Franklin, J.M., in press. Hydrothermal alteration associated with massive sulfide deposits, Middle Valley, northern Juan de Fuca Ridge. Can. Mineral.

\footnotetext{
-Abbreviations for names of organizations and publications in ODP reference lists follow the style given in Chemical Abstracts Service Source Index (published by American Chemical Society).
} 
Grinstead, R.R., and Snider, S., 1967. Modification of the curcumin method for low level boron determinations. Analyst, 92:532-533.

Hart, S.R., 1969. K, Rb, Cs contents and K/Rb, K/Cs ratios of fresh and altered submarine basalts. Earth Planet. Sci. Lett., 6:295-303.

Heinrichs, H., Schulz-Dobrick, B., and Wedepohl, K.H., 1980. Terrestrial geochemistry of $\mathrm{Cd}, \mathrm{Bi}, \mathrm{Tl}, \mathrm{Pb}, \mathrm{Zn}$, and $\mathrm{Rb}$. Geochim. Cosmochim. Acta, 44:1519-1533.

Johnson, J.W., Oelkers, E.H., and Helgeson, H.C., 1992. SUPCRT92: a software package for calculating the standard molal thermodynamic properties of minerals, gases, aqueous species, and reactions from 1 to 5000 Bar and 0 to $1000^{\circ} \mathrm{C}$. Comput. Geosci., 18:899-947.

Magenheim, A.J., and Gieskes, J.M., 1992. Hydrothermal discharge and alteration in near-surface sediments from the Guaymas Basin, Gulf of California. Geochim. Cosmochim. Acta, 56:2329-2338.

Mottl, M.J., and Holland, H.D., 1978. Chemical exchange during hydrothermal alteration of basalt by seawater. I. Experimental results for major and minor components of seawater. Geochim. Cosmochim. Acta, 42:11031115 .

Palmer, M.R., 1992. Controls over the chloride concentration of submarine hydrothermal vent fluids: evidence from $\mathrm{Sr} / \mathrm{Ca}$ and ${ }^{87} \mathrm{Sr} /{ }^{86} \mathrm{Sr}$ ratios. Earth Planet. Sci. Lett., 109:37-46.

Palmer, M.R., and Edmond, J.M., 1989. Cesium and rubidium in submarine hydrothermal fluids: evidence for recycling of alkali elements. Earth Planet. Sci. Lett., 95:8-14.

Parsons, T.R., Yoshiaki, M., and Lalli, C.M., 1984. A Manual of Chemical and Biological Methods for Seawater Analysis: Oxford (Pergamon Press).

Peter, J.M., and Scott, S.D., 1988. Mineralogy, composition, and fluid-inclusion microthermometry of seafloor hydrothermal deposits in the southern trough of Guaymas Basin, Gulf of California. Can. Mineral., 26:567-587.

Potter, R.W., II, and Brown, D.L., 1977. The volumetric properties of aqueous sodium chloride solutions from $0^{\circ} \mathrm{C}$ to $500^{\circ} \mathrm{C}$ at pressures up to 2000 bars based on a regression of available data in the literature. U.S. Geol. Surv. Bull., 1421-C:1-35.

Ryan, J.G., and Langmuir, C.H., 1987. The systematics of lithium abundances in young volcanic rocks. Geochim. Cosmochim. Acta, 51:1727-1741.
Seyfried, W.E., Ding, K., and Berndt, M.E., 1991. Phase equilibria constraints on the chemistry of hot spring fluids at mid-ocean ridges. Geochim. Cosmochim. Acta, 55:3559-3580.

Seyfried, W.E., Jr., 1987. Experimental and theoretical constraints on hydrothermal alteration processes at mid-ocean ridges. Annu. Rev. Earth Planet. Sci., 15:317-335.

Tivey, M.K., 1988. Physical and chemical controls on the growth of hydrothermal vent structures: a model of transport and chemical reaction [Ph.D. dissert.]. Univ. of Washington, Seattle.

Von Damm, K.L., 1990. Seafloor hydrothermal activity: black smoker chemistry and chimneys. Annu. Rev. Earth Planet. Sci., 18:173-204.

Von Damm, K.L., and Bischoff, J.L., 1987. Chemistry of hydrothermal solutions from the southern Juan de Fuca Ridge. J. Geophys. Res., 92:11334 11346.

Von Damm, K.L., Bischoff, J.L., and Rosenbauer, R.J., 1991. Quartz solubility in hydrothermal seawater: an experimental study and equation describing quartz solubility for up to $0.5 \mathrm{M} \mathrm{NaCl}$ solutions. Am. J. Sci., 291:977-1007.

Von Damm, K.L., Edmond, J.M., Measures, C.I., and Grant, B., 1985. Chemistry of submarine hydrothermal solutions at Guaymas Basin, Gulf of California. Geochim. Cosmochim. Acta, 49:2221-2237.

Westall, J.C., Zachary, J.L., and Morel, F.M.M., 1976. MINEQL, a computer program for the calculation of chemical equilibrium composition of aqueous systems. Mass. Inst. Technol., Dep. Civ. Eng., Tech. Note, 18.

You, C.-F., Butterfield, D.A., Spivack, A.J., Gieskes, J.M., Gamo, T., and Campbell, A.J., in press. Boron and halide systematics in submarine hydrothermal systems: effects of phase separation and sedimentary contributions. Earth Planet. Sci. Lett.

Date of initial receipt: 6 April 1993

Date of acceptance: 25 October 1993

Ms 139SR-266 